\title{
Expanding the toolbox of chemoselective modifications of protein-like polymers at methionine residues
}

Marie Rosselin, ${ }^{\text {a }}$ Ye Xiao, ${ }^{\mathrm{a}}$ Ludovic Belhomme, ${ }^{\mathrm{a}}$ Sébastien Lecommandoux ${ }^{\mathrm{a}}$ and Elisabeth Garanger*a

${ }^{a}$ Univ. Bordeaux, CNRS, Bordeaux INP, LCPO, UMR 5629, F-33600, Pessac, France.

\section{Materials and methods}

\section{I.1. Materials}

All of the reagents and solvents are commercially available from standard suppliers, except for oxaziridine derivatives that have been prepared following the published procedure. ${ }^{1}$ Methyl iodine, propylene oxide, allyl glycidyl ether, glycidyl propargyl ether, formic acid,

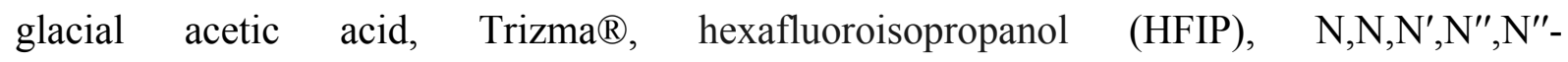
pentamethyldiethylenetriamine (PMDETA), sodium azide (99.5\%), 3-chloroperoxybenzoic acid $(\leq 77 \%)$ and sodium cyanate $(96 \%)$ were obtained from Sigma-Aldrich (FR). Deionized water (18 M $\Omega-\mathrm{cm})$ was obtained by using a Millipore Milli-Q Biocel A10 purification unit. Cuprisorb was purchased from Seachem. Ethanol (96.0\%, EtOH), methanol (98.5\%, MeOH), tetrahydrofuran (99\%), DMF (99\%), DCM (99.5\%), acetonitrile (99.9\%, ACN) and $\mathrm{CuSO}_{4} .5 \mathrm{H}_{2} \mathrm{O}$ were obtained from VWR international. 1-ethyl urea (98\%), benzaldehyde (99\%), potassium carbonate $(99 \%)$, propargylamine $(98 \%)$, and 3-chloropropylamine hydrochloride (98\%) and $\mathrm{NaCl}$ (99\%) was purchased from Alfa Aesar (FR). $\beta$-Dgalactopyranosyl azide $\left(\mathrm{Gal}-\mathrm{N}_{3}\right)$ was obtained from Carbosynth (UK). Ammonium Acetate and Ammonium pyrrolidinedithiocarbamate, APDC and sodium ascorbate were obtained from Fisher Scientific (FR). Titanium isopropoxide (98\%) was purchased from Acros Organics. Silica gel $60 \mathrm{M}$ was purchased from Macherey-Nagel. Amicon ${ }^{\circledR}$ ultra-15 centrifugal filter tube $3000 \mathrm{MWCO}$ was obtained from Merck millipore. Tris buffer was prepared with $0.05 \mathrm{M}$ of Trisma-HCland $0.15 \mathrm{M}$ of $\mathrm{NaCl}$ in Milli-Q water, the $\mathrm{pH}$ of the solution was then adjusted to 7.6 with $\mathrm{NaOH} 0.1 \mathrm{M}$.

\section{I.2. NMR spectrometry analysis}

${ }^{1} \mathrm{H}$ NMR analyses were performed in $\mathrm{D}_{2} \mathrm{O}$ at $298 \mathrm{~K}$ on a Bruker AVANCE III HD 400 apparatus equipped with a $5 \mathrm{~mm}$ Bruker multinuclear z-gradient direct probe operating at 400.2 MHz. The solvent signal was used as the reference signal $(\delta=4.79 \mathrm{ppm})$. HSQC analyses were performed on a Bruker AVANCE NEO 400 spectrometer operating at 100.7 
$\mathrm{MHz}$, equipped with a $5 \mathrm{~mm}$ Bruker multinuclear z-gradient direct cryoprobe-head operating at 298 K. Data processing was performed using Bruker Topspin Software.

\section{I.3. Transition temperature measurements}

Turbidity assays were performed on a Cary 100 Bio UV-visible spectrometer equipped with a multi-cell thermoelectric temperature controller from Varian (Palo Alto, CA) operating at 600 $\mathrm{nm}$ between $20^{\circ} \mathrm{C}$ and $80^{\circ} \mathrm{C}$ at a $1^{\circ} \mathrm{C} \cdot \mathrm{min}-1$ scan rate for ELP $\left[\mathrm{V}_{3} \mathrm{M}_{1}-40\right]$, compound $1 \mathrm{~A}, 1 \mathrm{~B}$, $1 \mathrm{C}$ and $1 \mathrm{D}$ in Tris buffer at four different concentrations $(25 \mu \mathrm{M}, 50 \mu \mathrm{M}, 125 \mathrm{M}$ and $250 \mu \mathrm{M})$.

\section{I.4. Size-exclusion chromatography (SEC)}

Measurements in water were performed on an Ultimate 3000 system from Thermoscientific equipped with diode array detector DAD. The system also include a multi-angles light scattering detector MALS and differential refractive index detector dRI from Wyatt technology. Polymers were separated on two TOSOH successive columns (one G4000PWXL (7.8*300) column with exclusion limits from 2000 Da to 300000 Da and one G3000PWXL (7.8*300) column with exclusion limit bellow $40000 \mathrm{Da})$. Measurements were performed at a flowrate of $0.6 \mathrm{~mL} / \mathrm{min}$ and columns temperature was held at $26^{\circ} \mathrm{C}$. Aqueous solvent composed by Acetic Acid (AcOH) 0.3 M, Ammonium Acetate 0.2 M and ACN (6.5/3.5, v/v) was used as the eluent. Ethylene glycol was used as flow marker.

\section{Experimental section}

\section{II.1. Alkylation}

Alkylation of ELP $\left[M_{1} V_{\mathbf{3}^{-40}}\right.$ (procedure A). ELP $\left[\mathrm{M}_{1} \mathrm{~V}_{3}-40\right]$ was dissolved in $0.2 \mathrm{M}$ aqueous formic acid (20 mg/mL). Alkyl halide (40 equiv. per Met residue) was added as a solution in THF $(50 \mathrm{mg} / \mathrm{mL})$. The reaction was stirred for 5 days at room temperature under Argon atmosphere. The excess of alkyl halide was removed by extraction with diethyl ether, the organic layer was pipetted off and discarded. The aqueous phase was then transferred to a 3,000 MWCO ultra-centrifugal filter tube and washed with $40 \mathrm{~mL}$ of Milli-Q water at $20^{\circ} \mathrm{C}$. The product was lyophilized to dryness to give a white powder.

Alkylation of ELP $\left[\mathbf{M}_{\mathbf{1}} \mathbf{V}_{\mathbf{3}} \mathbf{- 4 0}\right]$ (procedure B). ELP $\left[\mathrm{M}_{1} \mathrm{~V}_{3}-40\right]$ was dissolved an AcOH/HFIP mixture $(9 / 1, \mathrm{v} / \mathrm{v})$ at $20 \mathrm{mg} / \mathrm{mL}$. The solution was degassed with Ar. and the epoxide was added to the mixture (10 equiv. per methionine residue). After $24 \mathrm{~h}$ of stirring, a second portion of epoxide (10 equiv. per methionine residue) was added and the reaction was stirred 
$48 \mathrm{~h}$ in total, at room temperature and under Ar. atmosphere. The obtained mixture was transferred into a 3000 MWCO Amicon ${ }^{\circledR}$ ultra-15 centrifugal filter tube, washed with $40 \mathrm{~mL}$ of Milli-Q water and freeze-dried.

\section{II.1.1. Alkylation of ELP[M $\left[\mathrm{M}_{3^{-}}-40\right]$ with alkyl halide: Route (A)}

Compound 1A. Alkylation with methyl iodine, procedure A. ${ }^{1} \mathrm{H}$ NMR $\left(400 \mathrm{MHz}, \mathrm{D}_{2} \mathrm{O}\right.$, $\left.25^{\circ} \mathrm{C}\right)$ : (main peaks) $\delta 4.67-4.61(\mathrm{~m}, 11 \mathrm{H}, \mathrm{CH} \alpha \mathrm{Met}), \delta 4.47-4.40(\mathrm{~m}, 80 \mathrm{H}, \mathrm{CH} \alpha \mathrm{Val}$ and Pro, VPGXG), 4.18-4.16 (d, $30 \mathrm{H}, \mathrm{CH} \alpha$ Val, VPGVG), 3.41-3.37 (t, 22H, $\underline{\mathrm{CH}}_{2} \mathrm{~S}$ Met), 2.95-2.94 (d, $66 \mathrm{H}, \mathrm{SCH}_{3}$ Met), 1.00-0.93 (br m, $420 \mathrm{H}, \mathrm{CH}_{3} \mathrm{Val}$ ). Yield= $61 \%$.

\section{II.1.2. Alkylation of ELP $\left[M_{1} V_{3^{-}}-40\right]$ with epoxide: Route (B)}

Compound 1B. Alkylation with propylene oxide, procedure B. ${ }^{1} \mathrm{H}$ NMR $\left(400 \mathrm{MHz}, \mathrm{D}_{2} \mathrm{O}\right.$, $\left.25^{\circ} \mathrm{C}\right)$ : (main peaks) $\delta 4.66-4.63(\mathrm{~m}, 11 \mathrm{H}, \mathrm{CH} \alpha \mathrm{Met}), \delta 4.48-4.41(\mathrm{~m}, 80 \mathrm{H}, \mathrm{CH} \alpha \mathrm{Val}$ and Pro, VPGXG), 4.37-4.28 (m, 11H, CHOH Met, signal $\beta$ ), 4.19-4.17 (d, $30 \mathrm{H}, \mathrm{CH} \alpha$ Val, VPGGㅡ), 3.59-3.39 (m, 22H, $\mathrm{CHCH}_{2} \mathrm{~S}$ Met, signal $\alpha$ ), 3.01-2.98 (dd, $33 \mathrm{H}, \mathrm{SCH}_{3} \mathrm{Met}$ ), 1.38-1.36 (dd, $33 \mathrm{H}, \mathrm{CH}_{3} \mathrm{CHOH}$ Met, signal $\gamma$ ), 1.00-0.93 (br m, $420 \mathrm{H}, \mathrm{CH}_{3}$ Val). Yield= 88 \%. MS-ESI: Theoretical MW = 17684.9 Da, Experimental [M11]11+=1607.4 Da.

Compound 2B. Alkylation with glycidyl propargyl ether, procedure B. ${ }^{1} \mathrm{H}$ NMR $(400 \mathrm{MHz}$, $\mathrm{D}_{2} \mathrm{O}, 25^{\circ} \mathrm{C}$ ): (main peaks) $\delta 4.66-4.62(\mathrm{~m}, 11 \mathrm{H}, \mathrm{CH} \alpha \mathrm{Met}), \delta 4.47-4.41$ (m, $80 \mathrm{H}, \mathrm{CH} \alpha \mathrm{Val}$ and Pro, VPGXG), 4.38-4.36 (m, $11 \mathrm{H}, \mathrm{CHOH}$ Met, signal $\beta$ ), 4.29-4.28 (d, $22 \mathrm{H}, \mathrm{CH}_{2}$ Met, signal $\delta), 4.18-4.16\left(\mathrm{~d}, 30 \mathrm{H}, \mathrm{CH} \alpha\right.$ Val, VPGVG), 3.63-3.52 (m, $22 \mathrm{H}, \mathrm{CHCH}_{2} \mathrm{~S}$ Met, signal a), 3.03-3.00 (dd, $33 \mathrm{H}, \mathrm{SCH}_{3} \mathrm{Met}$ ), 2.95 (t, $3 \mathrm{H}, \mathrm{CH}$ alkyne), 1.38-1.36 (dd, $33 \mathrm{H}$, $\underline{\mathrm{CH}}_{3} \mathrm{CHOH}$ Met), 1.00-0.94 (br m, $420 \mathrm{H}, \mathrm{CH}_{3}$ Val). Yield= 86 \%. MS-ESI: Theoretical MW $=18279.1 \mathrm{Da}$, Experimental $[\mathrm{M} 11] 11+=1661.8 \mathrm{Da}$.

Compound 3B. Alkylation with allyl glycidyl ether, procedure B. ${ }^{1} \mathrm{H}$ NMR $\left(400 \mathrm{MHz}, \mathrm{D}_{2} \mathrm{O}\right.$, $\left.25^{\circ} \mathrm{C}\right)$ : (main peaks) $\delta$ 6.01-5.91 (m, $11 \mathrm{H}, \mathrm{CH}$ alkene, signal $\left.\varepsilon\right), \delta 5.37-5.27\left(\mathrm{~m}, 22 \mathrm{H}, \mathrm{CH}_{2}\right.$ alkene, signal \#), 4.64-4.62 (m, $11 \mathrm{H}, \mathrm{CH} \alpha \mathrm{Met}), \delta$ 4.47-4.40 (m, $80 \mathrm{H}, \mathrm{CH} \alpha \mathrm{Val}$ and Pro, VPGXG), 4.37-4.35 (m, 11 H, CHOH Met, signal $\beta$ ), 4.18-4.16 (d, 30 H, CH $\alpha$ Val, VPGVG), 4.11-4.10 (d, $22 \mathrm{H}, \mathrm{CH}_{2}$ Met, signal $\delta$ ), 3.02-2.99 (dd, $33 \mathrm{H}, \mathrm{SCH}_{3} \mathrm{Met}$ ), 1.00-0.93 (br m, $420 \mathrm{H}, \mathrm{CH}_{3}$ Val). Yield= $89 \%$, functionalization $95 \%$. 


\section{II.1.3. Alkylation of ELP $\left[M_{1} V_{3}-40\right]$ with oxaziridine: Route (C)}

\section{Synthesis of oxaziridine derivatives (ReACT method)}

A

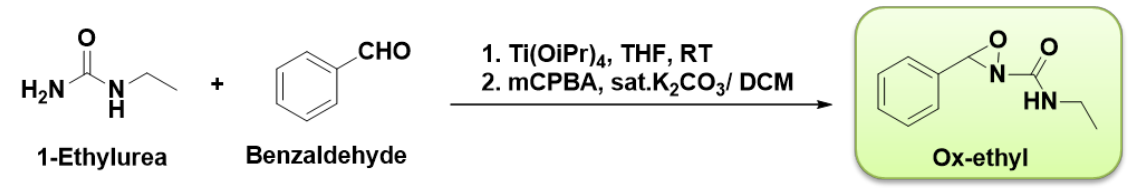

B
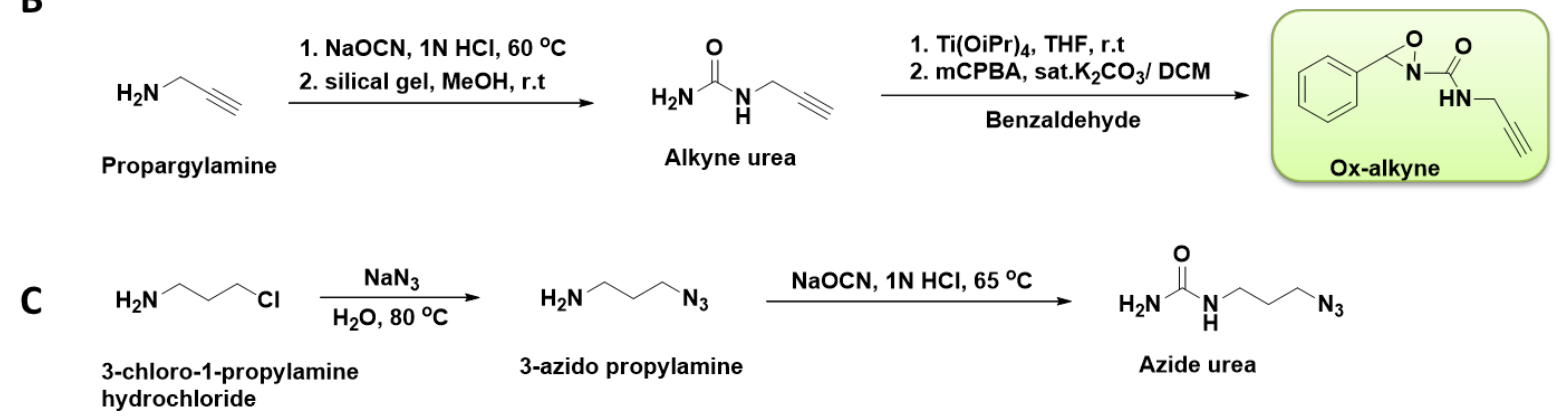
hydrochloride

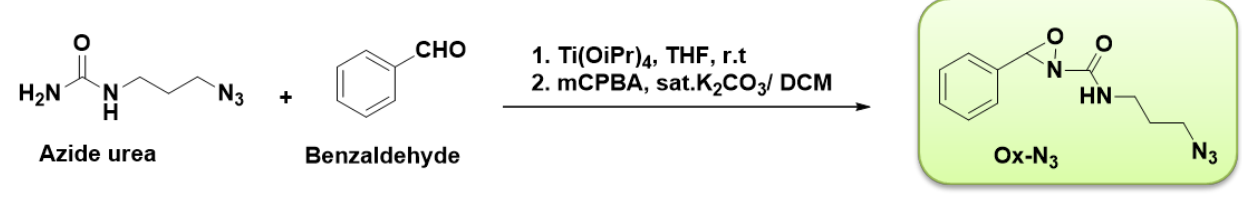

Oxaziridine derivatives were synthesized follow the procedure reported by Lin and cocoworkers. ${ }^{1}$ Briefly, the synthetic strategy were based on the amination of benzaldehyde by urea to generate imine and the imine was subsequently oxidized by mCPBA to form oxaziridine derivatives. The chemical shift of the only proton on oxaziridine ring was found $4.92 \mathrm{ppm}$ in ${ }^{1} \mathrm{H}$ NMR spectra of ox-ethyl, ox-alkyne, ox- $\mathrm{N}_{3}$, which are in agreement with the literature data.

General procedure of alkylation with oxaziridine. To a solution of ELP $\left[\mathrm{V}_{3} \mathrm{M}_{1}-40\right](50 \mathrm{mg}$, $2.9 \mu \mathrm{M})$ in degassed water $(50 \mathrm{~mL})$ under Ar. atmosphere was added a solution of oxaziridine derivative synthesized as described by Lin and co-workers ${ }^{1}$ (6 equiv. per Met) in DMF (200 $\mu \mathrm{L})$. After stirring for 30-60 mins, DCM $(20 \mathrm{~mL})$ was added and the mixture was extracted with DCM for two times to remove the benzaldehyde. The combined water layers were then dialyzed (MW. cut 3k) against Milli-Q water for $12 \mathrm{~h}$ (changing water every $4 \mathrm{~h}$ ). The final product was obtained by lyophilization.

Compound 1C. Alkylation with ethyl-oxaziridine (Ox-ethyl). ${ }^{1} \mathrm{H}$ NMR (400 MHz, $\mathrm{D}_{2} \mathrm{O}$, $\left.25^{\circ} \mathrm{C}\right)$ : (main peaks) $\delta$ 4.47-4.40 (m, $80 \mathrm{H}, \mathrm{CH} \alpha$ Val and Pro, VPGXG), 4.18-4.17 (d, $30 \mathrm{H}$, $\mathrm{CH} \alpha$ Val, VPGG), 3.14-3.09 (q, 22 H, $\mathrm{CH}_{2}$ Met signal $\alpha$ ), 3.07-2.95 (m, $22 \mathrm{H}, \mathrm{CH}_{2} \mathrm{~S}$ Met, 
signal 1), 2.70 (s, $33 \mathrm{H}, \mathrm{SCH}_{3} \mathrm{Met}$ ), 1.09-1.05 (dt, $33 \mathrm{H}, \underline{\mathrm{CH}_{3}} \mathrm{CH}_{2}$ Met, signal $\beta$ ), 1.00-0.93 (br m, $420 \mathrm{H}, \mathrm{CH}_{3} \mathrm{Val}$ ). Yield $=63 \%$.

Compound 2C. Alkylation with oxaziridine-alkyne (Ox-alkyne). ${ }^{1} \mathrm{H}$ NMR (400 MHz, $\mathrm{D}_{2} \mathrm{O}$, $\left.25^{\circ} \mathrm{C}\right)$ : (main peaks) $\delta$ 4.47-4.40 (m, $80 \mathrm{H}, \mathrm{CH} \alpha$ Val and Pro, VPGXG), 4.18-4.17 (d, $30 \mathrm{H}$, $\mathrm{CH} \alpha$ Val, VPGG), 3.13-3.01 (m, $22 \mathrm{H}, \mathrm{CH}_{2}$ Met signal 1), 2.73 (s, $33 \mathrm{H}, \mathrm{SCH}_{3} \mathrm{Met}$ ), 2.58 (t, 11 H, CH-Alkyne, signal $\beta$ ), 1.00-0.93 (br m, 420 H, $\mathrm{CH}_{3}$ Val). Yield = $94 \%$.

Compound 3C. Alkylation with oxaziridine-azide $\left(\mathrm{Ox}-\mathrm{N}_{3}\right) .{ }^{1} \mathrm{H} \mathrm{NMR}\left(400 \mathrm{MHz}, \mathrm{D}_{2} \mathrm{O}, 25^{\circ} \mathrm{C}\right)$ : (main peaks) $\delta$ 4.47-4.41 (m, $80 \mathrm{H}, \mathrm{CH} \alpha$ Val and Pro, VPGXG), 4.19-4.17 (d, $30 \mathrm{H}, \mathrm{CH} \alpha$ Val, VPGG), 6.40-3.36 36 (t, $22 \mathrm{H}, \underline{\mathrm{CH}}_{2}-\mathrm{N}_{3}$, signal $\gamma$ ), 3.24-3.20 (t, $22 \mathrm{H}, \underline{\mathrm{CH}}_{2}-\mathrm{NH}$ Met signal $\alpha$ ), 3.13-3.03 (m, $22 \mathrm{H}, \mathrm{CH}_{2} \mathrm{~S}$ Met, signal 1), 2.75 (bs, $33 \mathrm{H}, \mathrm{SCH}_{3} \mathrm{Met}$ ), 1.80-1.73 (q, $22 \mathrm{H},-\mathrm{CH}_{2}-\mathrm{CH}_{2}-\mathrm{CH}_{2}-$ Met, signal $\beta$ ), $1.00-0.93$ (br m, $420 \mathrm{H}, \mathrm{CH}_{3}$ Val). Yield $=85 \%$.

\section{II.2. Demethylation}

Demethylation of modified-ELP (compound 1D). To a solution of modified- ELP $\left[\mathrm{M}_{1} \mathrm{~V}_{3}\right.$ 40] $(50 \mathrm{mg}, 10 \mathrm{mM}))$ in $75 \% \mathrm{EtOH}(\mathrm{aq})$ was added ammonium pyrrolidinedithiocarbamate (APDC) (5.0 equiv per Met residue). The solution was stirred under Ar. for $24 \mathrm{~h}$ at room temperature. The obtained mixture was transferred to a $1 \mathrm{kDa}$ MWCO dialysis bag and dialyzed against 50\% $\mathrm{MeOH}(\mathrm{aq})$ during $24 \mathrm{~h}$ with 3 solvent changes followed by $8 \mathrm{~h}$ dialysis against Milli-Q water with 3 changes. The dialysis bag contents were then lyophilized to provide demethylated ELPs. ${ }^{1} \mathrm{H}$ NMR $\left(400 \mathrm{MHz}, \mathrm{D}_{2} \mathrm{O}, 25^{\circ} \mathrm{C}\right.$ ): (main peaks) $\delta 4.58-4.55$ (m, $11 \mathrm{H}, \mathrm{CH} \alpha \mathrm{Met}), \delta$ 4.47-4.40 (m, 80 H, CH $\alpha$ Val and Pro, VPGXG), 4.19-4.17 (d, $30 \mathrm{H}, \mathrm{CH} \alpha$ Val, VPGG), 2.70-2.55 (m, $22 \mathrm{H}, \underline{\mathrm{CH}_{2}} \mathrm{~S}$, signal 1), 1.25-1.23 (d, $\left.33 \mathrm{H}, \underline{\mathrm{CH}} 3 \mathrm{CHOH}\right)$, $1.00-0.93$ (br m, $420 \mathrm{H}, \mathrm{CH}_{3}$ Val). Yield $=44 \%$.

\section{II.3. Click-Reaction}

II.3.1. Click reaction in water. To a solution of ELP $\left[M_{1} \mathrm{~V}_{3}-40\right]$ derivative in degassed water ( $5 \mathrm{mg} / \mathrm{mL}$ ) under Ar. Atmosphere, the desired azido-galactose (1.5 equiv. per alkyne) was added. A solution of $\mathrm{Cu}(\mathrm{I})$ was prepared by addition of sodium ascorbate (1.3 equiv. per alkyne) to a degassed solution of $\mathrm{Cu}(\mathrm{II}) \mathrm{SO} 4$ (0.26 equiv. per alkyne) and pentamethyldiethylenetriamine ( 0.26 equiv. per alkyne) in Milli-Q water. The fresh $\mathrm{Cu}(\mathrm{I})$ solution was then transferred to the reaction mixture with a syringe. The reaction was stirred under Ar. at room temperature for $72 \mathrm{hrs}$. Cuprisorb was added to remove cupper by shaking 
overnight. Few drops of an aqueous solution of EDTA $(0.15 \mathrm{M})$ were added and the solution was purified by ultracentrifugation with Amicon ${ }^{\circledR} 3000$ MWCO ultra-centrifugal filter tube against Milli-Q water $(40 \mathrm{~mL})$. The remaining mixture was lyophilized.

Compound 4B. Click-reaction of compound 4B with $\beta$-D-galactopyranosyl azide. ${ }^{1} \mathrm{H}$ NMR $\left(400 \mathrm{MHz}, \mathrm{D}_{2} \mathrm{O}, 25^{\circ} \mathrm{C}\right):($ main peaks) $\delta 8.34(\mathrm{~s}, 11 \mathrm{H}, \mathrm{CH}$ triazole, signal *), $\delta$ 5.74-5.72 (d, $\left.11 \mathrm{H}, \mathrm{CH}_{1}{ }^{\prime}\right), \delta$ 4.65-4.61 (m, $\left.11 \mathrm{H}, \mathrm{CH} \alpha \mathrm{Met}\right), \delta$ 4.47-4.42 (m, $80 \mathrm{H}, \mathrm{CH} \alpha \mathrm{Val}$ and Pro, VPGXG), 4.40-4.36 (m, 11 H, CHOH Met, signal $\beta$ ), 4.18-4.16 (d, 30 H, CH $\alpha$ Val, VPGG), 3.81-3.80 (d, $11 \mathrm{H}, \mathrm{CH}_{6}$ ), 299-2.97 (m, $33 \mathrm{H}, \mathrm{SCH}_{3} \mathrm{Met}$ ), 1.00-0.92 (br m, $420 \mathrm{H}, \mathrm{CH}_{3} \mathrm{Val}$ ). Yield $=71 \%$.

II.3.2. Click reaction in DMSO. To a solution of ELP $\left[\mathrm{M}_{1} \mathrm{~V}_{3}-40\right]$ derivative in degassed DMSO (10 mg/mL) under Ar. Atmosphere, Cu(II)SO4 (0.05 equiv. per alkyne), sodium ascorbate (0.2 equiv. per alkyne) and tris((1-benzyl-4-triazolyl)methyl)amine TBTA (0.05 equiv. per alkyne) were added followed by the azido-galactose ( 0.05 equiv. per alkyne) dissolved in DMSO. The reaction was stirred under Ar. at room temperature for $72 \mathrm{hrs} ., 4 \mathrm{~mL}$ of Milli-Q water were added, the mixture was cooled at $4^{\circ} \mathrm{C}$ during $20 \mathrm{~min}$. and TBTA was precipitate and removed by centrifuge. Cuprisorb was added to remove cupper by shaking overnight. Few drops of an aqueous solution of EDTA $(0.15 \mathrm{M})$ were added and the solution was purified by dialysis using an Amicon ${ }^{\circledR} 3000$ MWCO ultra-centrifugal filter tube against Milli-Q water (40 mL). The remaining mixture was lyophilized.

Compound 4C. Click-reaction of compound $4 \mathrm{C}$ with $\beta$-D-galactopyranosyl azide. ${ }^{1} \mathrm{H}$ NMR $\left(400 \mathrm{MHz}, \mathrm{D}_{2} \mathrm{O}, 25^{\circ} \mathrm{C}\right)$ : (main peaks) $\delta 8.06(\mathrm{~s}, 11 \mathrm{H}, \mathrm{CH}$ triazole, signal *), $\delta$ 5.61-5.59 (d, $\left.11 \mathrm{H}, \mathrm{CH}^{1}{ }^{\prime}\right), \delta$ 4.39-4.33 (m, $91 \mathrm{H}, \mathrm{CH} \alpha \mathrm{Val}$ and Pro, VPGXG and $\left.\mathrm{CH}_{2} \alpha\right), 4.11-4.09$ (d, 30 $\mathrm{H}, \mathrm{CH} \alpha$ Val, VPGVG), 4.03-4.02 (m, $11 \mathrm{H}, \mathrm{CH}^{5}$ ), 3.73-3.71 (d, $22 \mathrm{H}, \mathrm{CH}_{2}{ }^{6}$ ), 0.92-0.86 (br m, $\left.420 \mathrm{H}, \mathrm{CH}_{3} \mathrm{Val}\right)$. Yield $=84 \%$. 


\section{Supplementary figures}

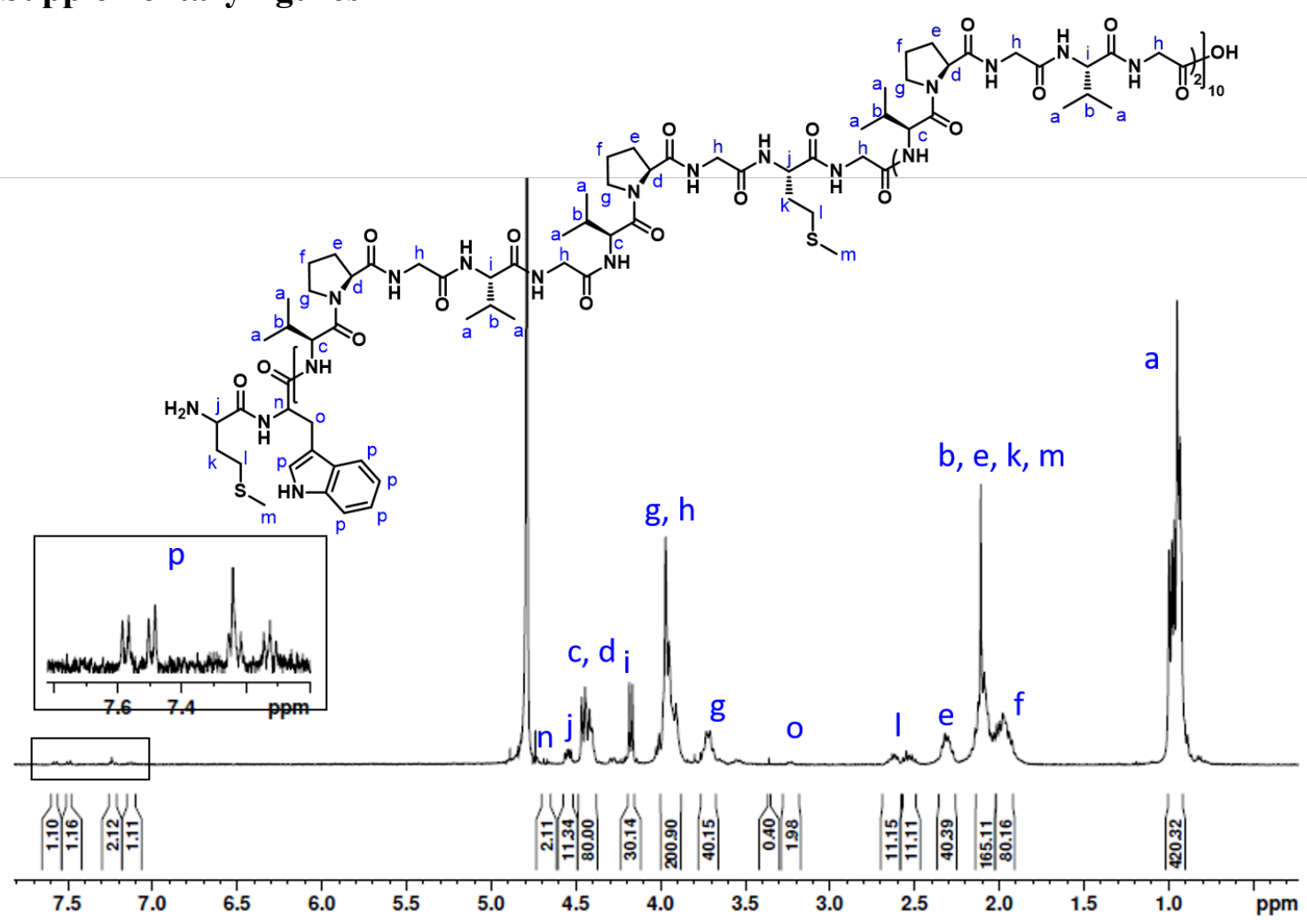

Figure S1. ${ }^{1} \mathrm{H}$ NMR spectrum of ELP $\left[\mathrm{V}_{3} \mathrm{M}_{1}-40\right]$ in $\mathrm{D}_{2} \mathrm{O}$

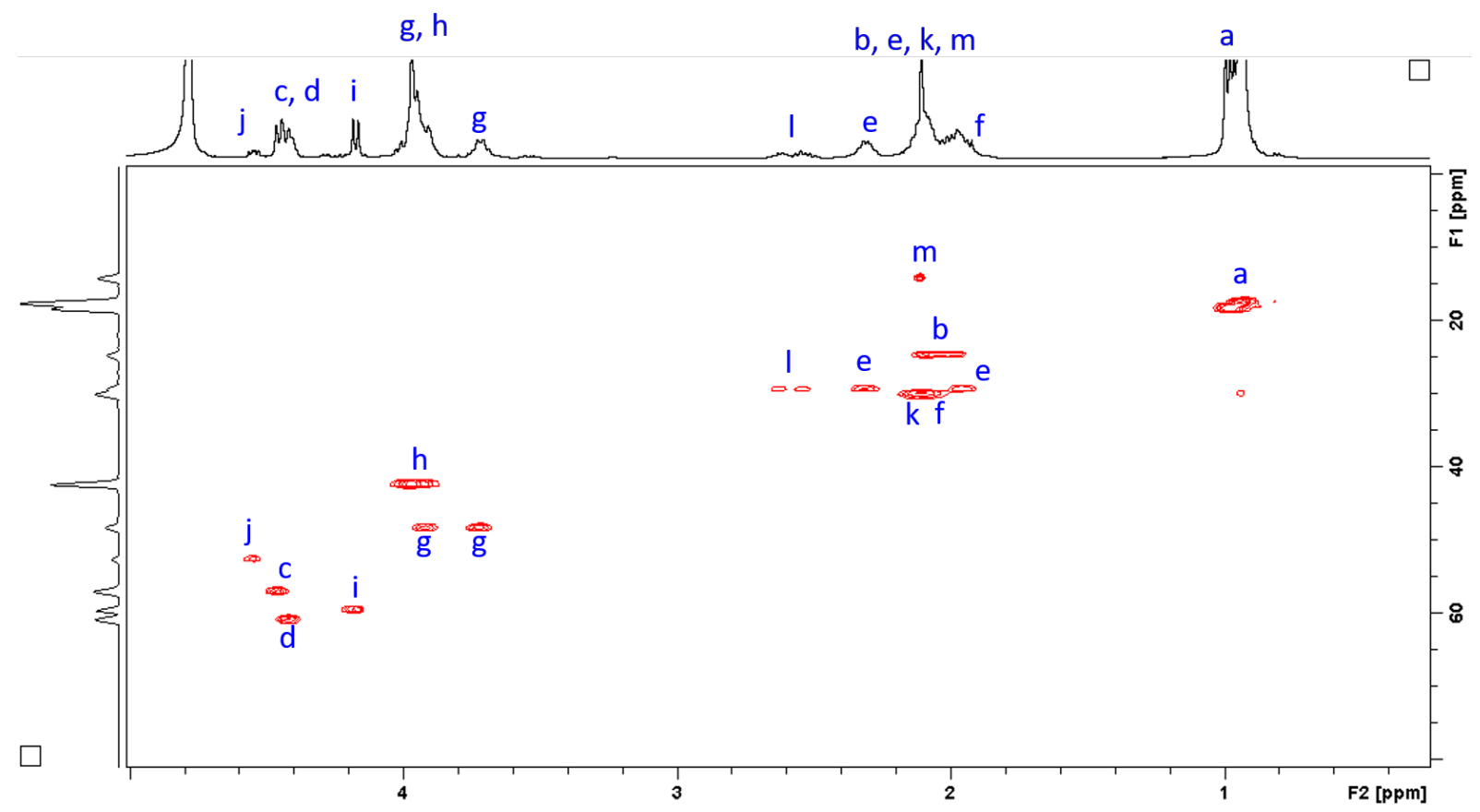

Figure S2. 2D NMR spectrum of ELP $\left[\mathrm{V}_{3} \mathrm{M}_{1}-40\right]$ in $\mathrm{D}_{2} \mathrm{O}$, HSQC 


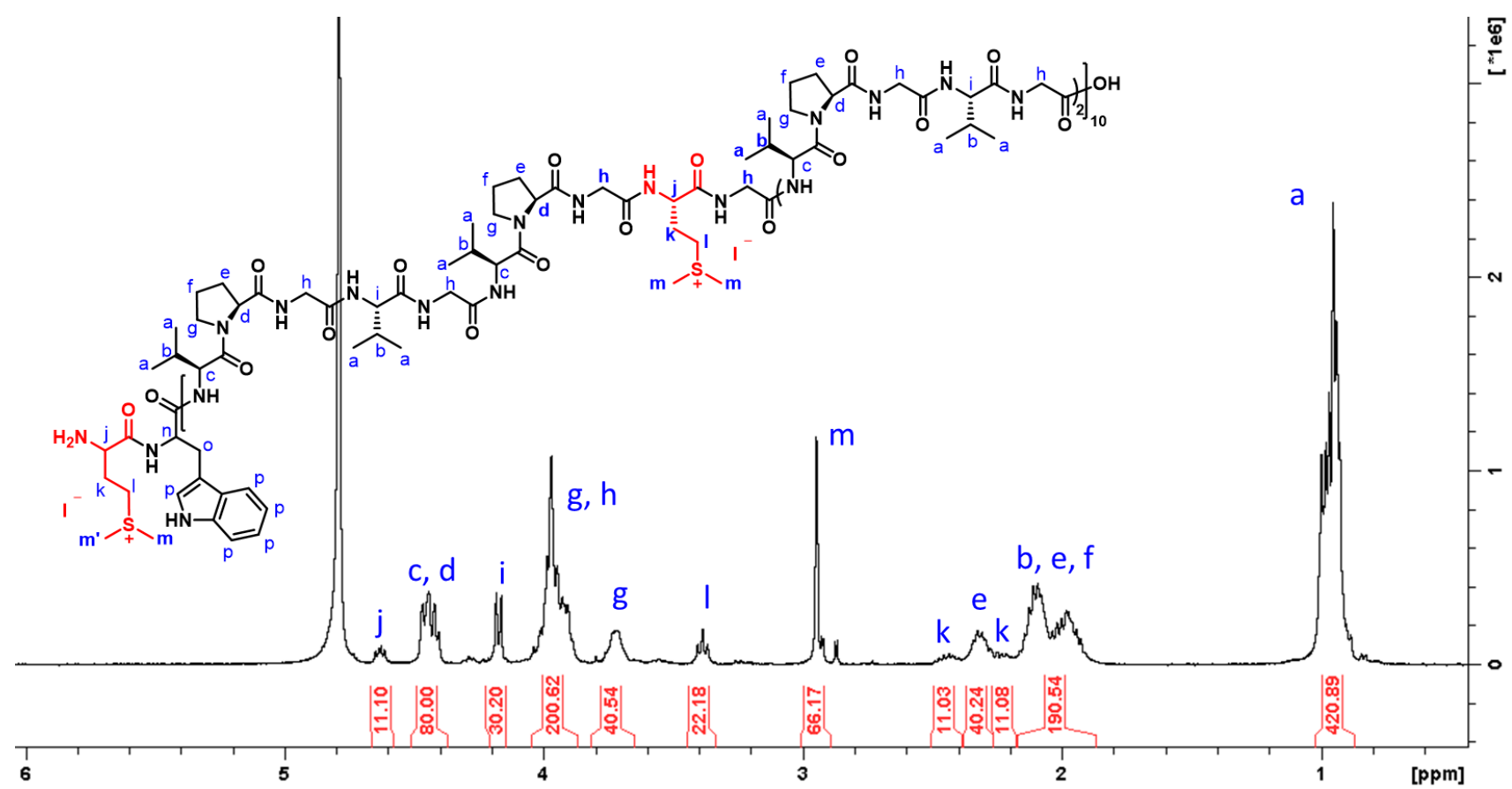

Figure S3. ${ }^{1} \mathrm{H}$ NMR spectrum of compound $1 \mathrm{~A}$ in $\mathrm{D}_{2} \mathrm{O}$

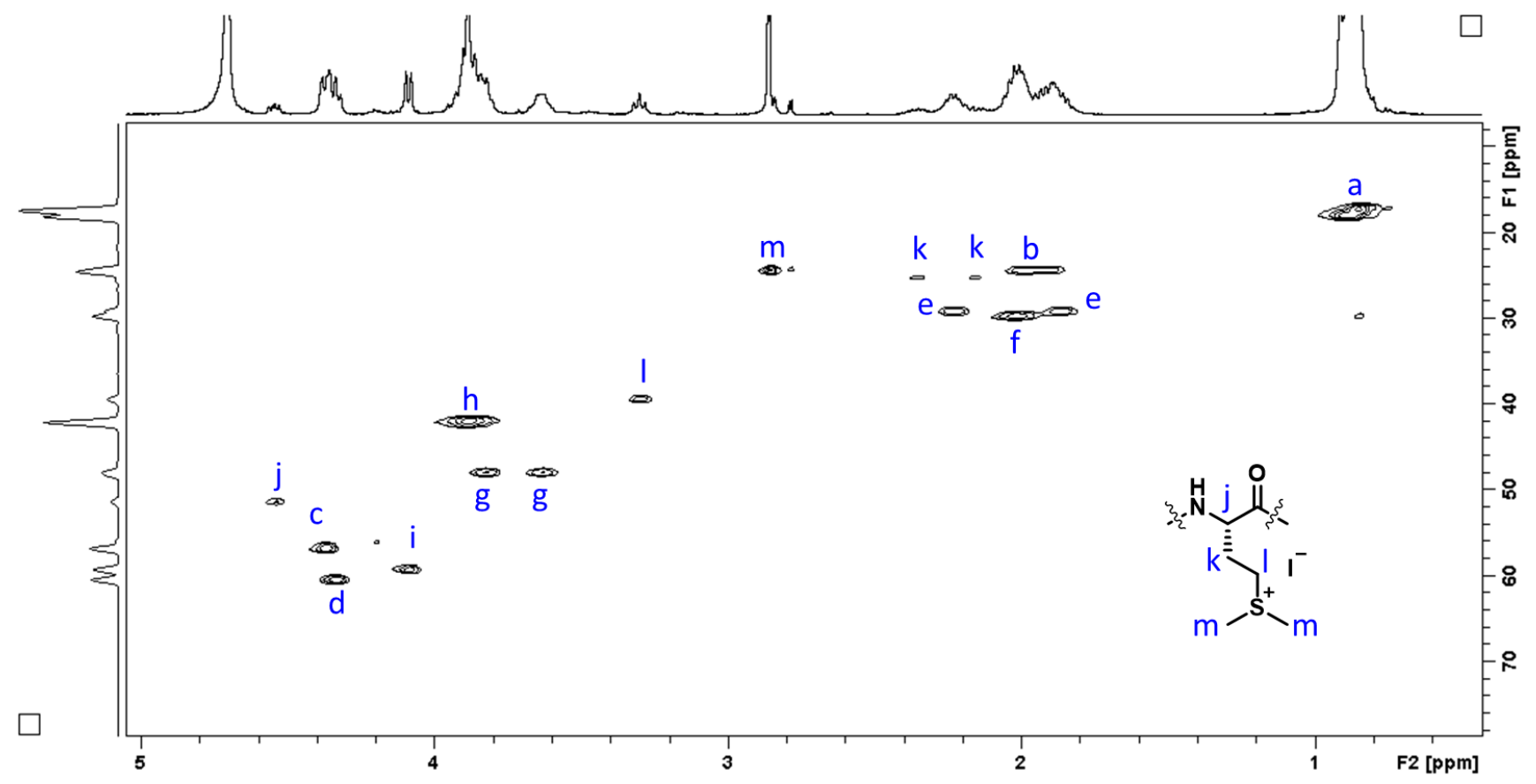

Figure S4. 2D NMR spectrum of compound 1A in $\mathrm{D}_{2} \mathrm{O}$, HSQC 


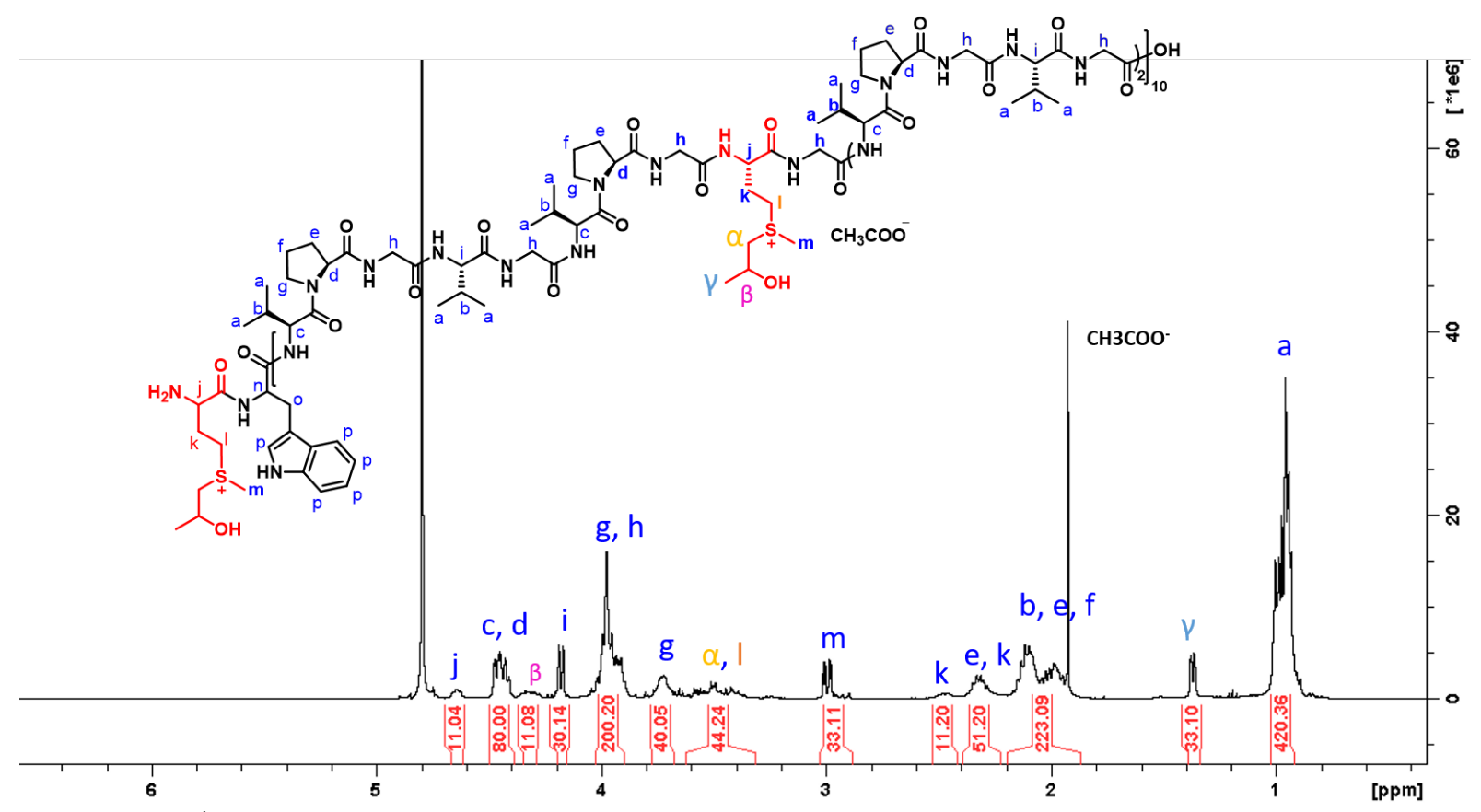

Figure S5. ${ }^{1} \mathrm{H}$ NMR spectrum of compound $1 \mathrm{~B}$ in $\mathrm{D}_{2} \mathrm{O}$

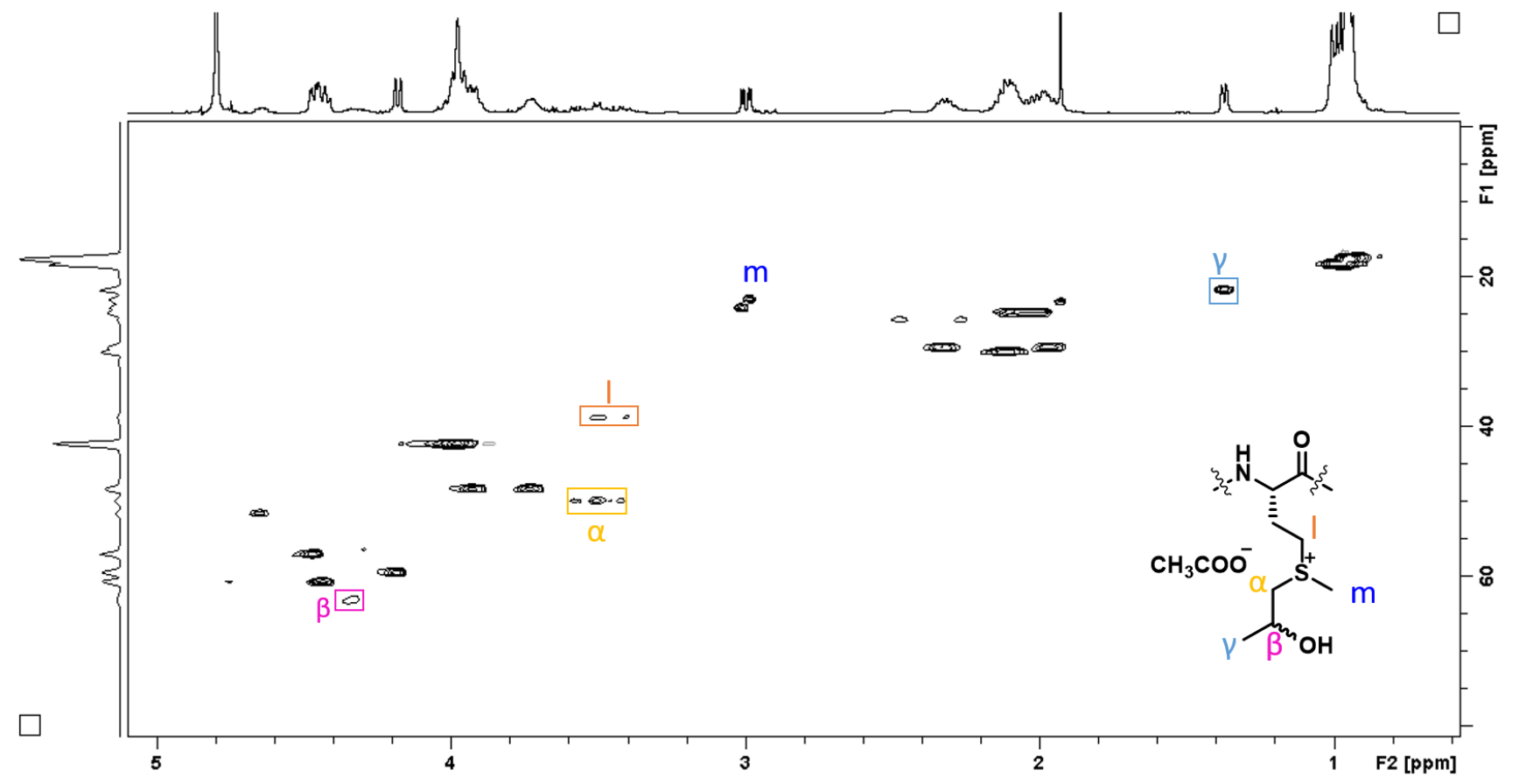

Figure S6. 2D NMR spectrum of compound 1B in $\mathrm{D}_{2} \mathrm{O}$, HSQC 


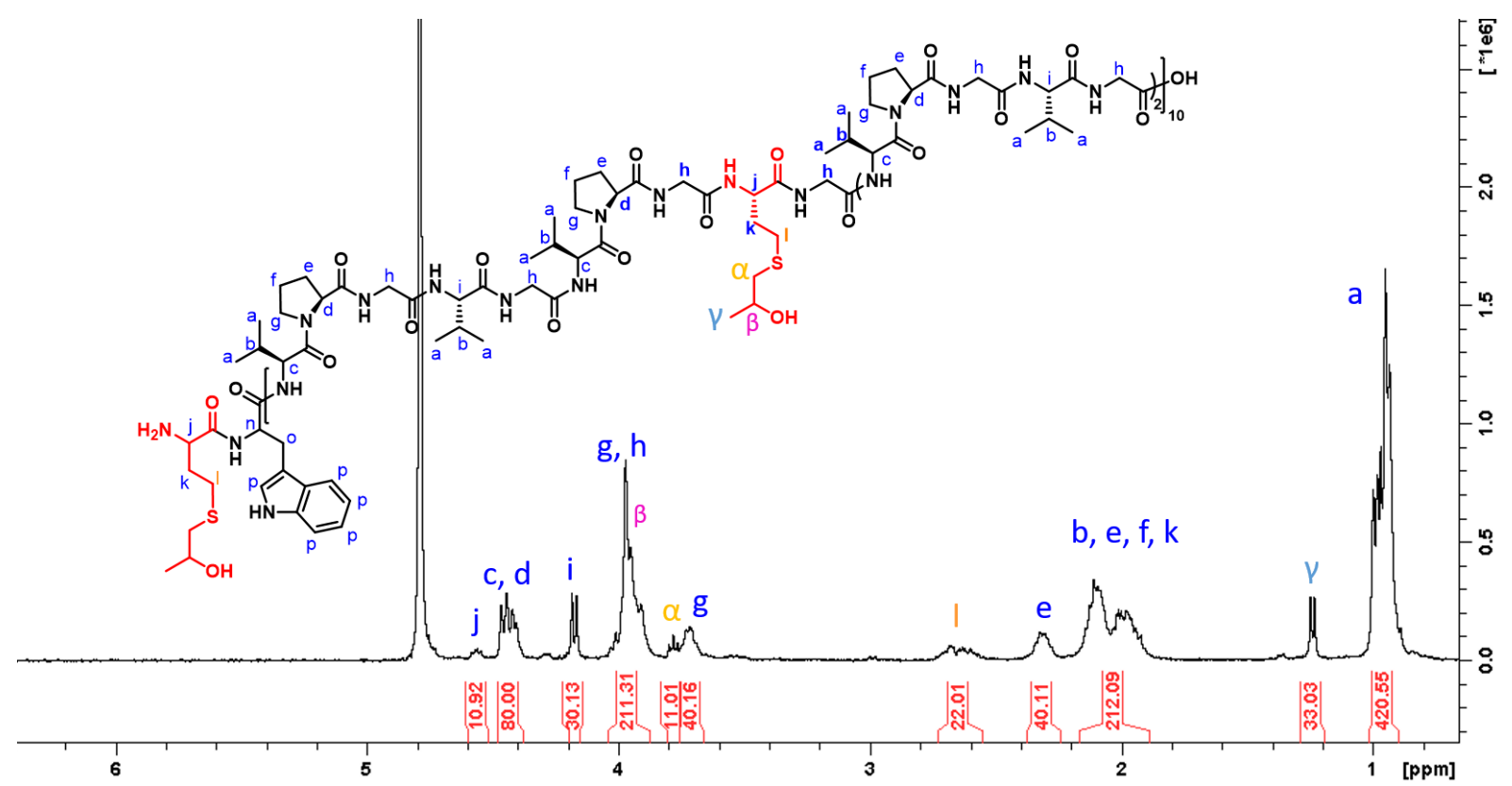

Figure S7. ${ }^{1} \mathrm{H}$ NMR spectrum of compound $1 \mathrm{D}$ in $\mathrm{D}_{2} \mathrm{O}$

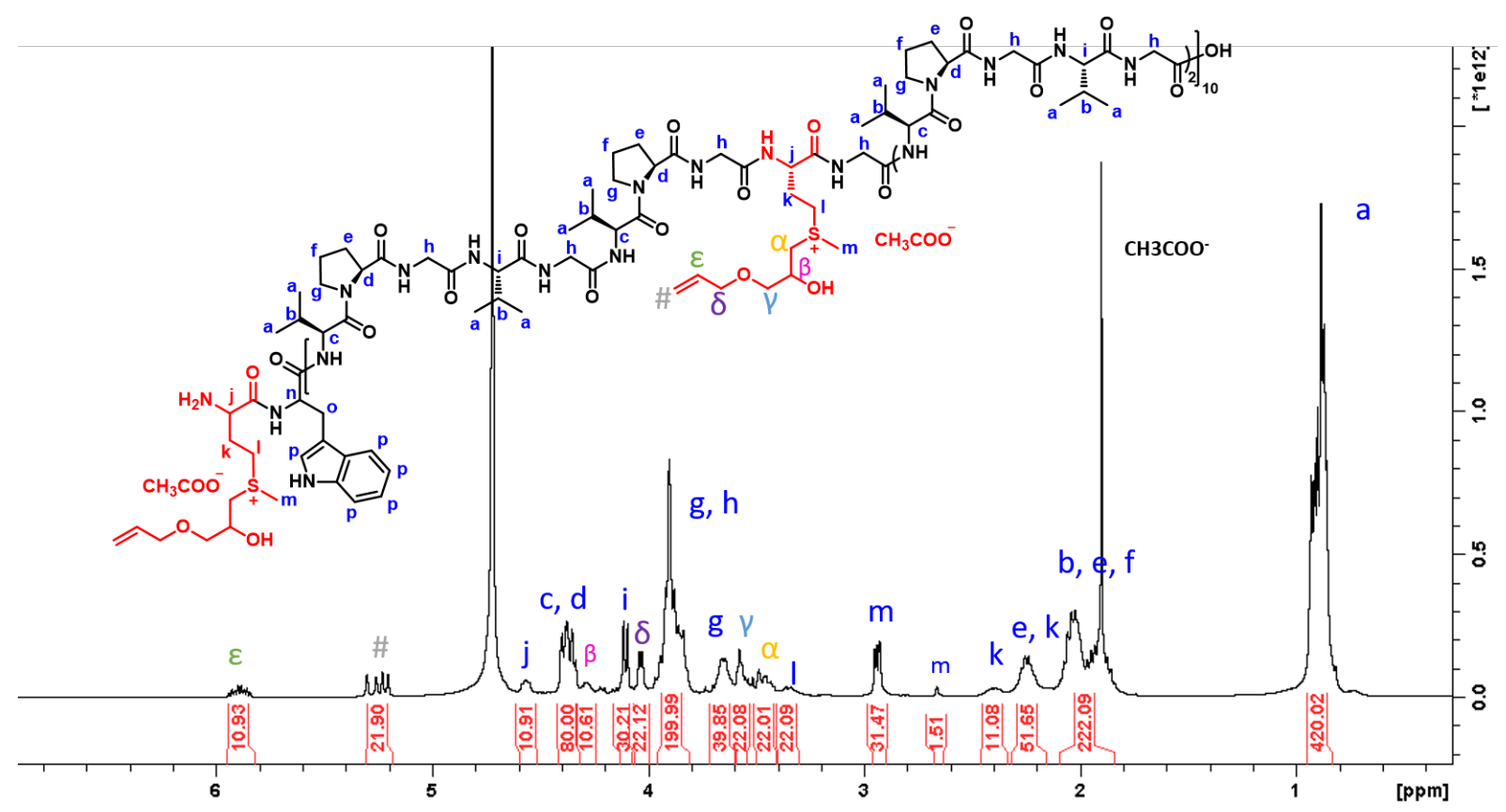

Figure S8. ${ }^{1} \mathrm{H}$ NMR spectrum of compound $3 \mathrm{~B}$ in $\mathrm{D}_{2} \mathrm{O}$ 


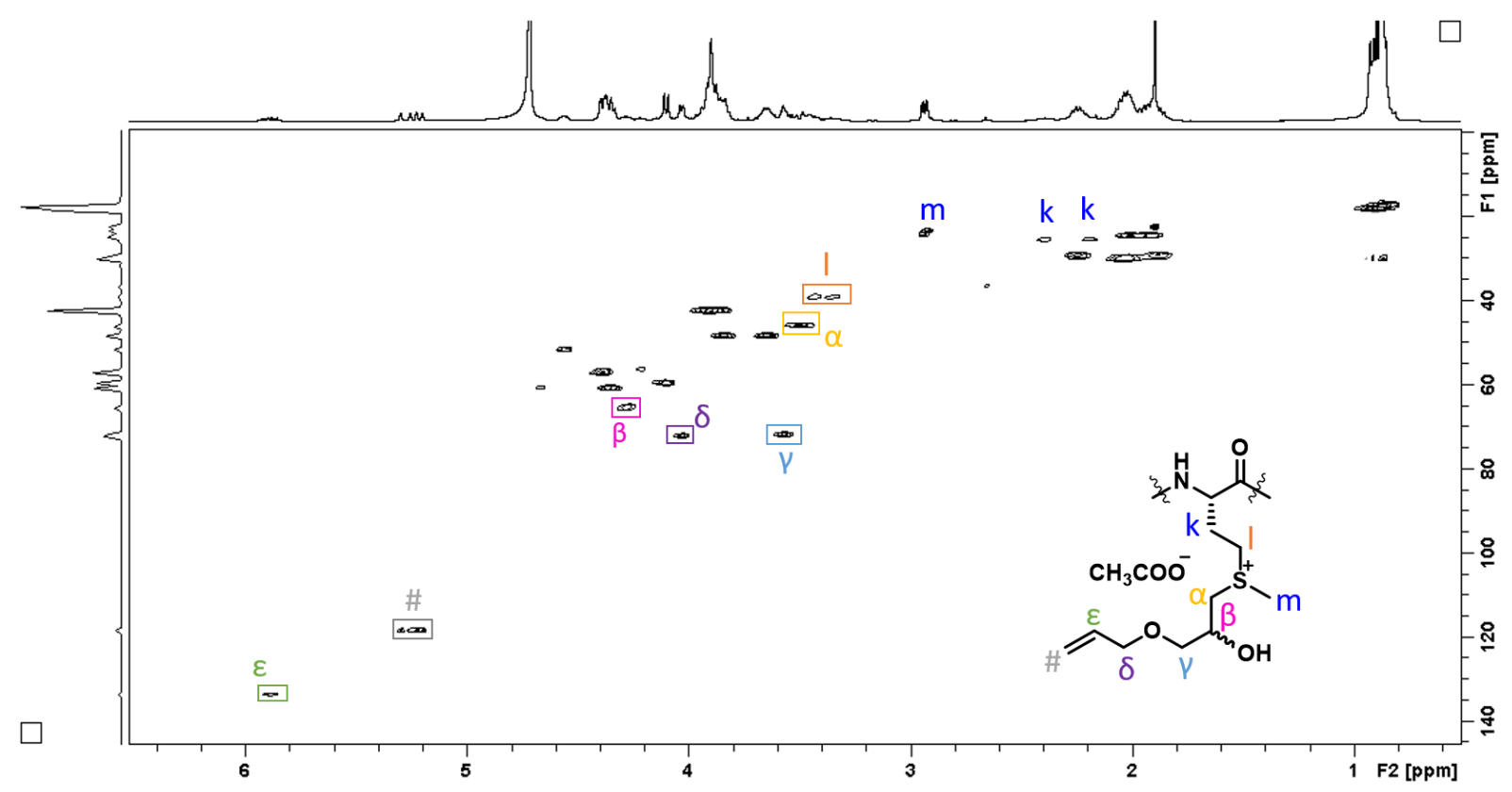

Figure S9. 2D NMR spectrum of compound 3B in $\mathrm{D}_{2} \mathrm{O}$, HSQC

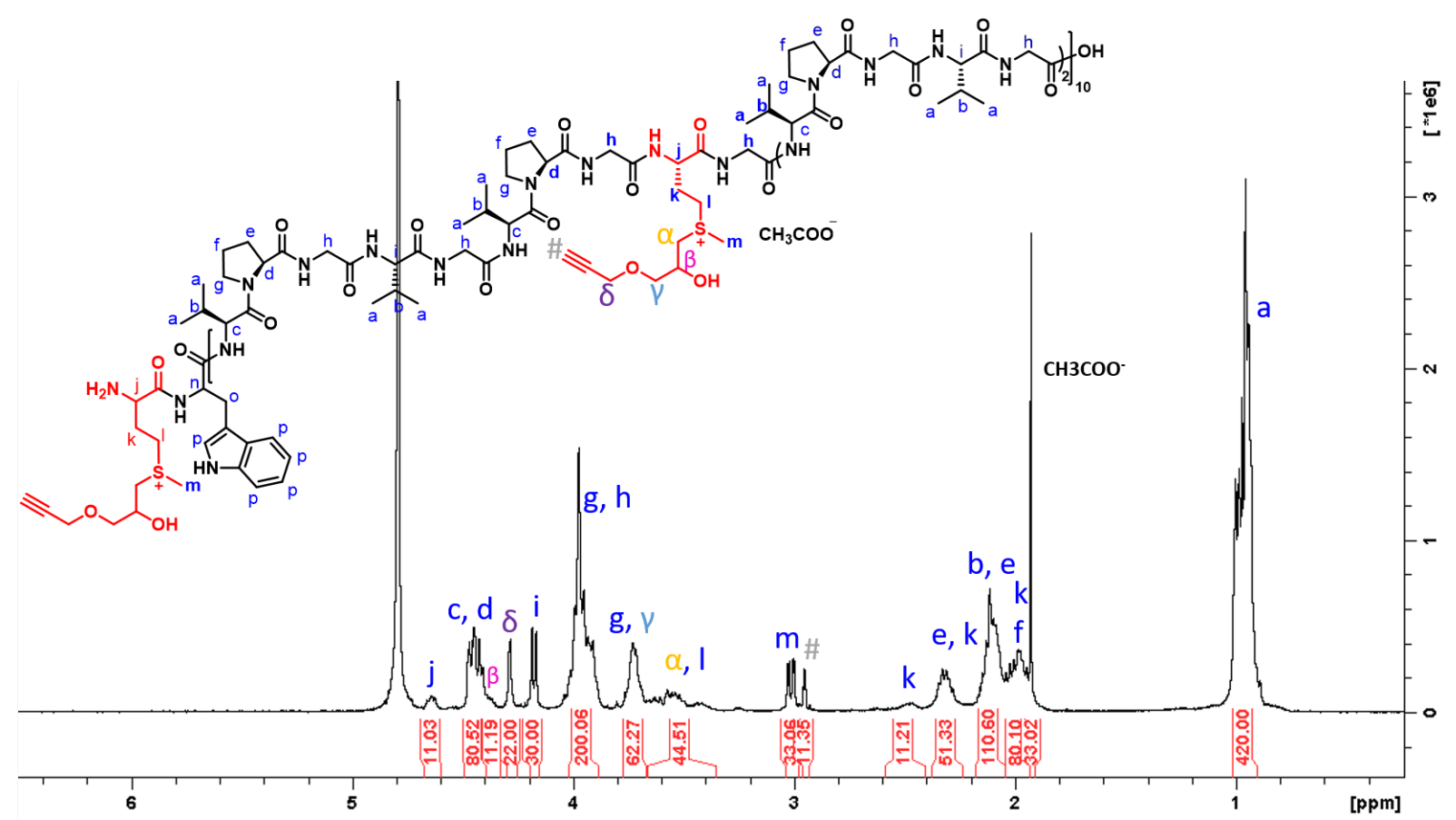

Figure S10. ${ }^{1} \mathrm{H}$ NMR spectrum of compound $2 \mathrm{~B}$ in $\mathrm{D}_{2} \mathrm{O}$ 


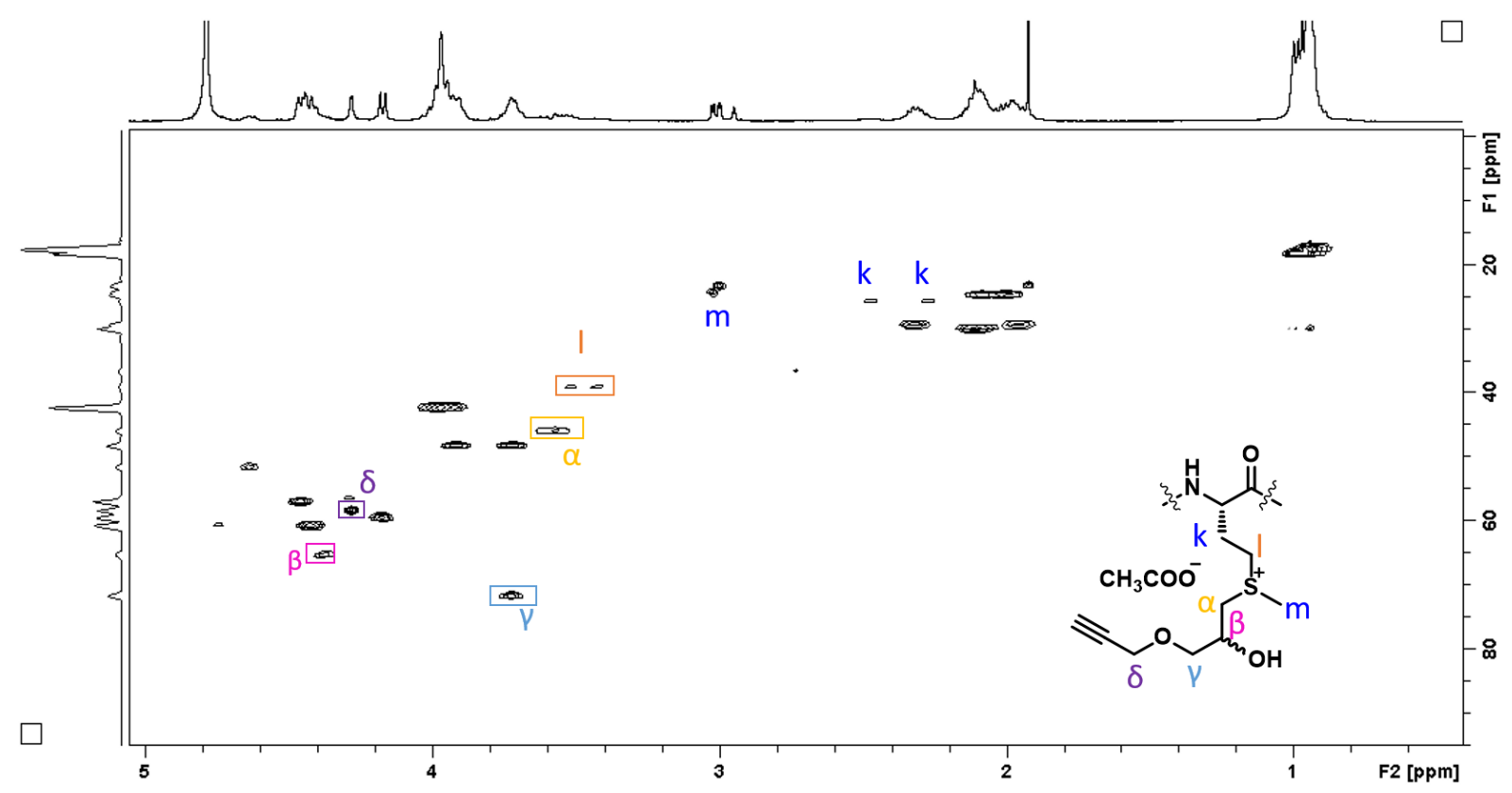

Figure S11. 2D NMR spectrum of compound 2B in $\mathrm{D}_{2} \mathrm{O}$, HSQC

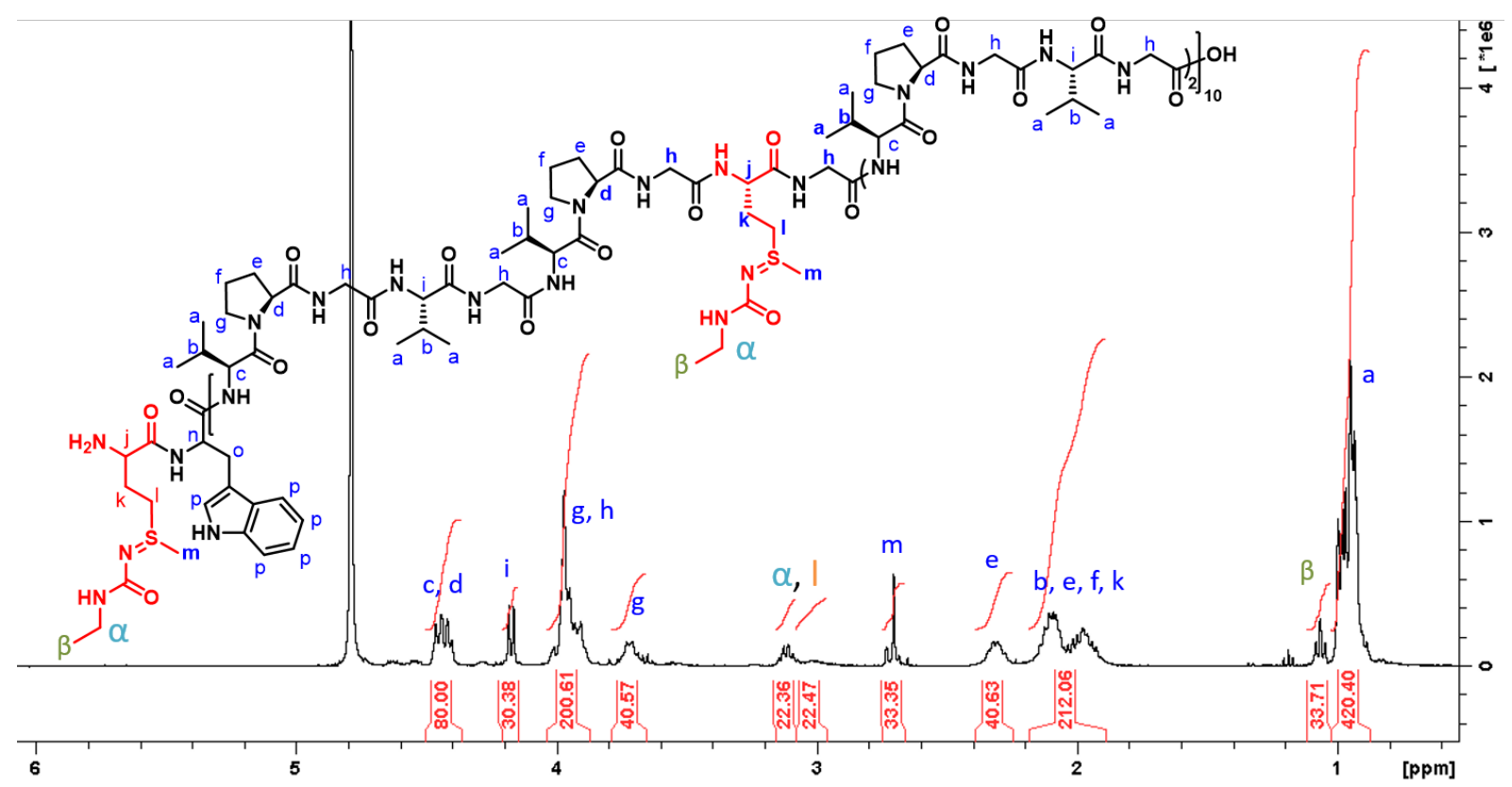

Figure S12. ${ }^{1} \mathrm{H}$ NMR spectrum of compound $1 \mathrm{C}$ in $\mathrm{D}_{2} \mathrm{O}$ 


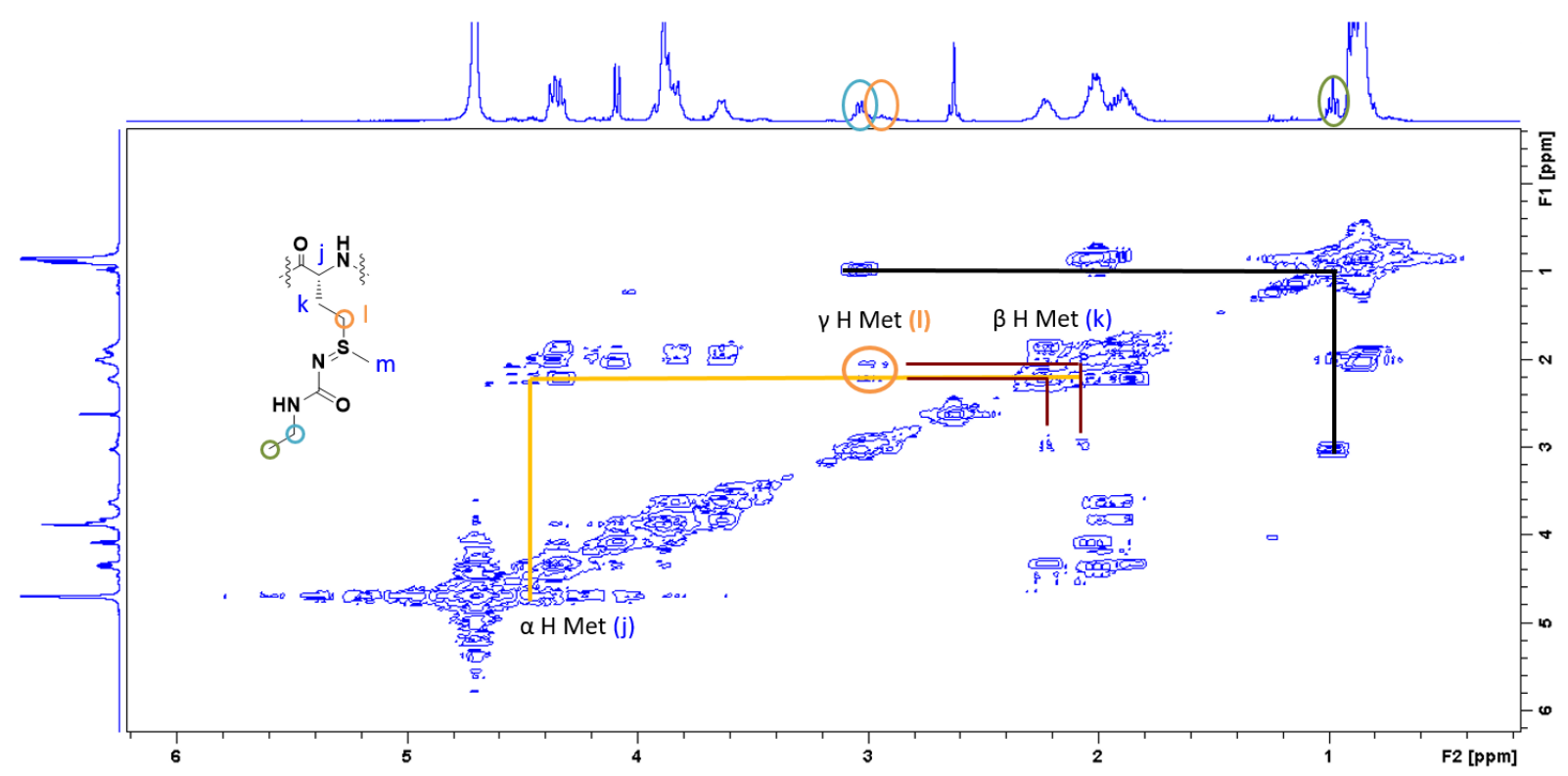

Figure S13. 2D NMR spectrum of compound $1 \mathrm{C}$ in $\mathrm{D}_{2} \mathrm{O}, \mathrm{COSY}$

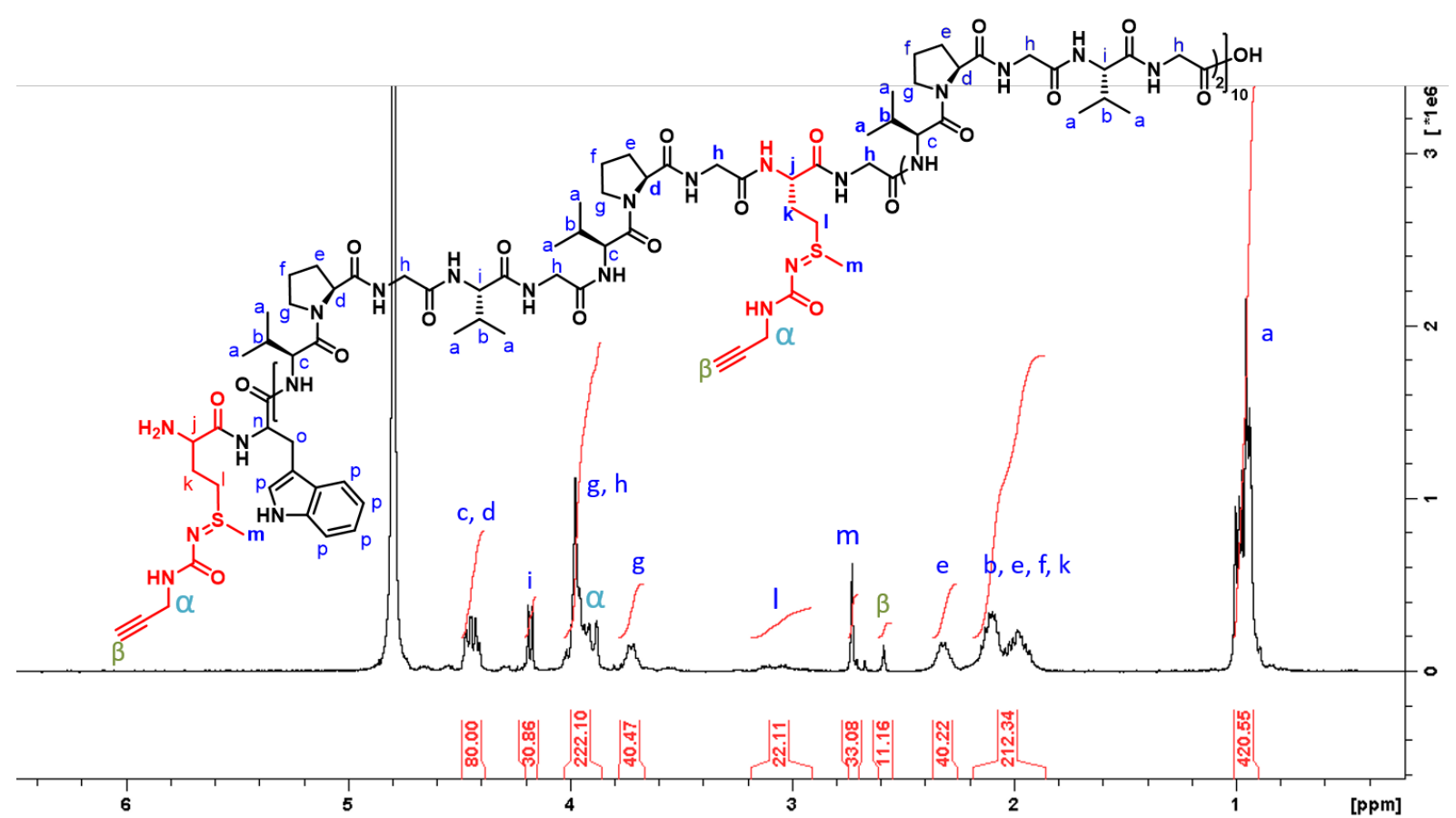

Figure S14. ${ }^{1} \mathrm{H}$ NMR spectrum of compound $2 \mathrm{C}$ in $\mathrm{D}_{2} \mathrm{O}$ 


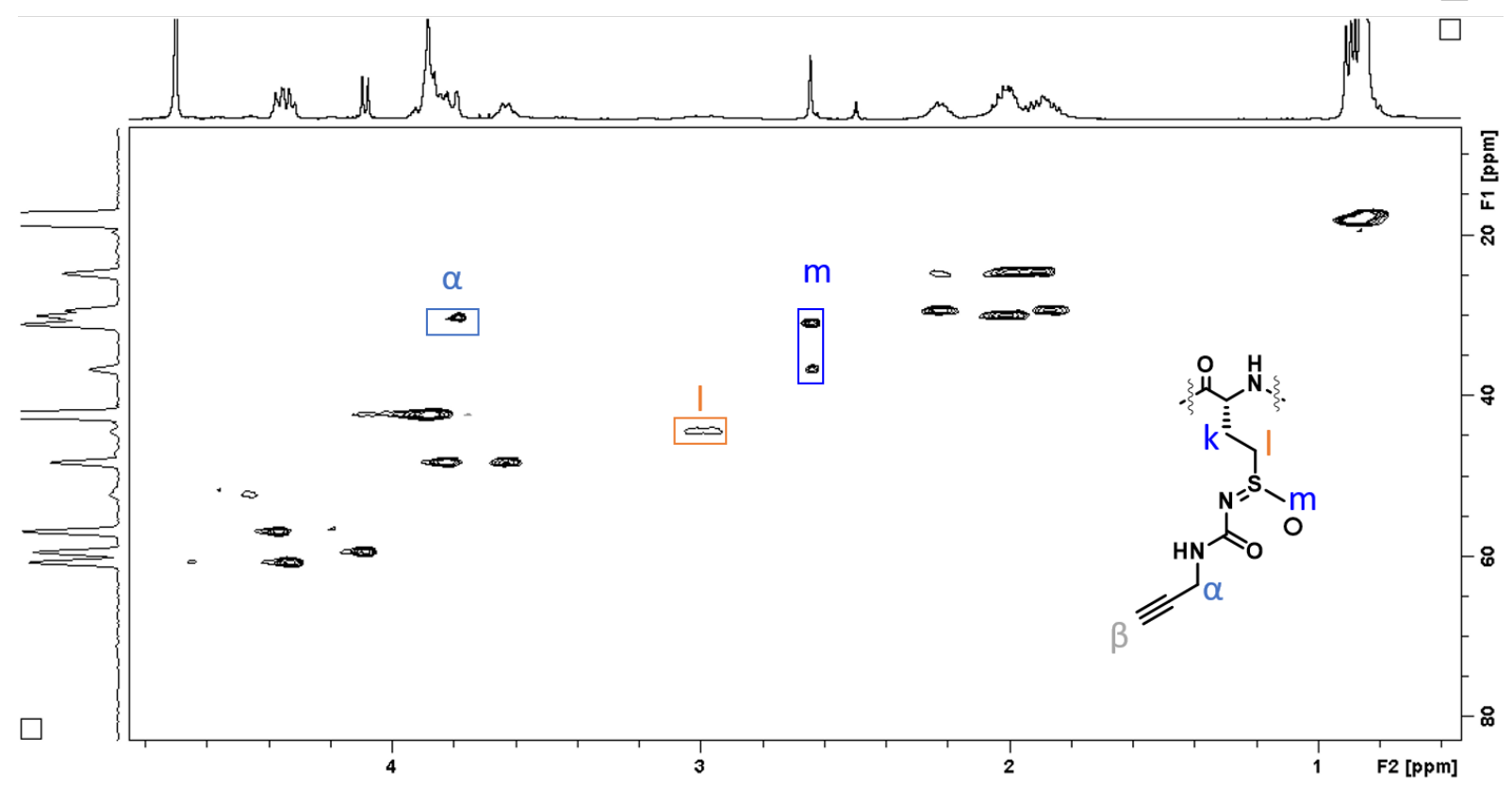

Figure S15. 2D NMR spectrum of compound $2 \mathrm{C}$ in $\mathrm{D}_{2} \mathrm{O}$, HSQC

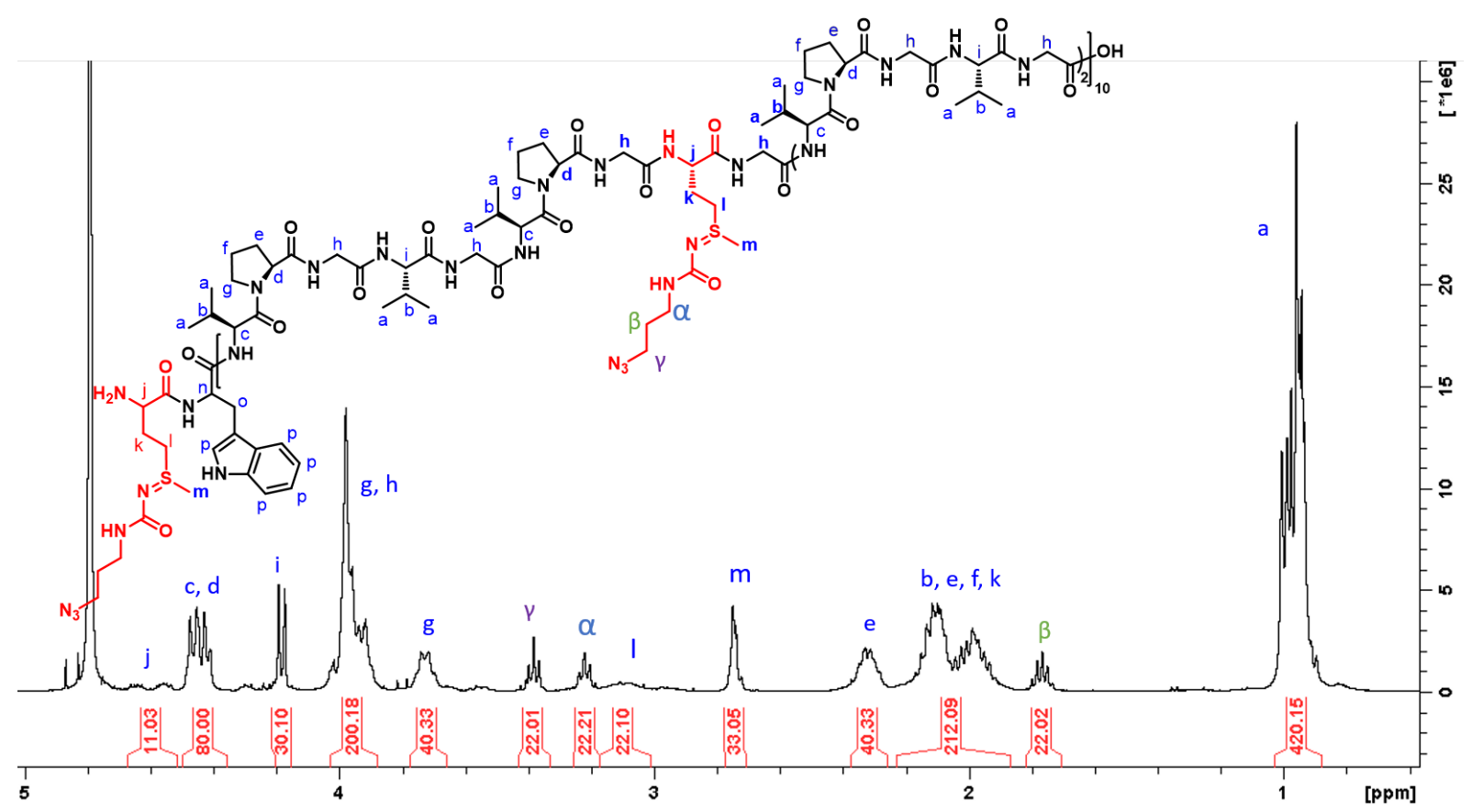

Figure S16. ${ }^{1} \mathrm{H}$ NMR spectrum of compound $3 \mathrm{C}$ in $\mathrm{D}_{2} \mathrm{O}$ 


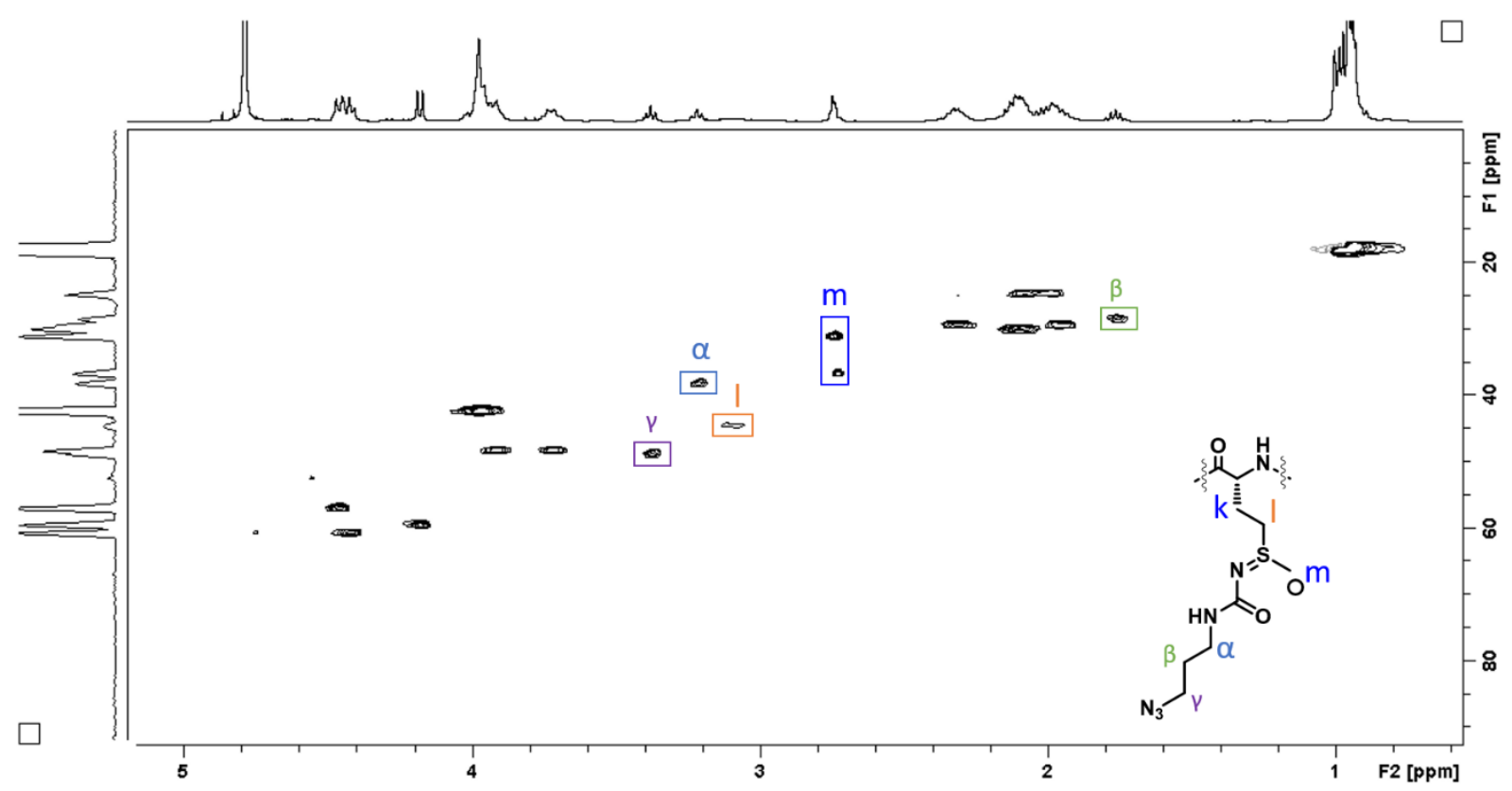

Figure S17. 2D NMR spectrum of compound $3 \mathrm{C}$ in $\mathrm{D}_{2} \mathrm{O}$, HSQC

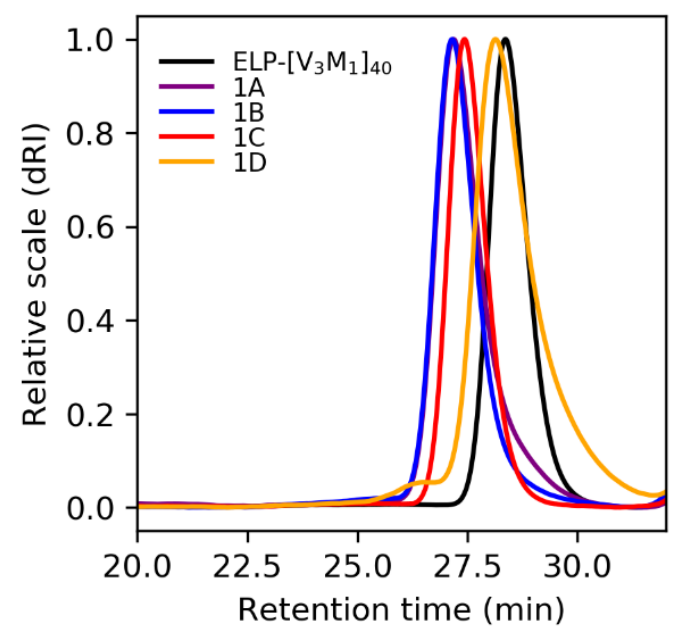

Figure S18. Size exclusion chromatography of ELP $\left[\mathrm{M}_{1} \mathrm{~V}_{3}-40\right]$, compound $1 \mathrm{~A}, 1 \mathrm{~B}, 1 \mathrm{C}$ and $1 \mathrm{D}$ in $\mathrm{AcOH} / \mathrm{Ammonium}$ Acetate/ACN eluent.
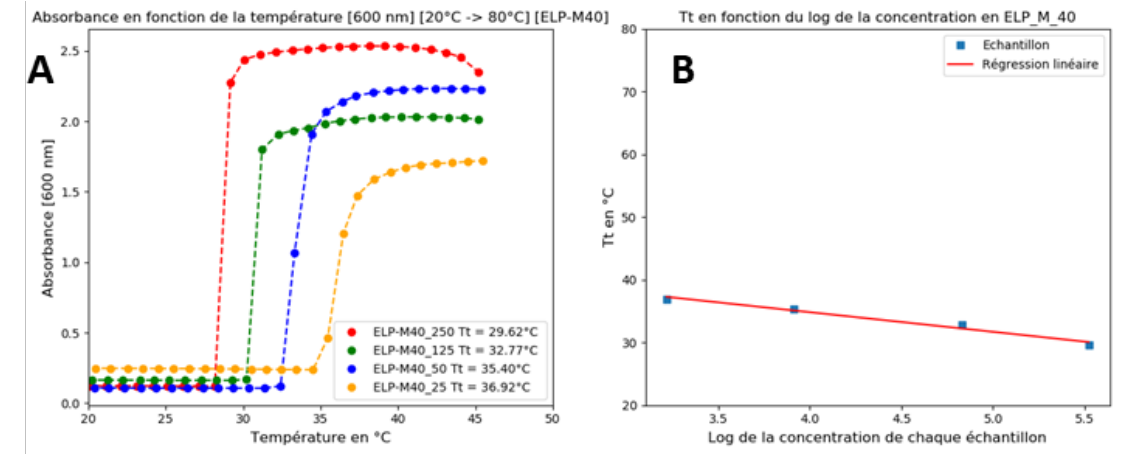

Figure S19. (A) Absorbance of $125 \mu \mathrm{M}$ solutions of ELP $\left[\mathrm{V}_{3} \mathrm{M}_{1}-40\right]$ in Tris buffer as function of temperature. (B) $\mathrm{Tt}$ values of ELP $\left[\mathrm{V}_{3} \mathrm{M}_{1}-40\right]$, plotted as functions of sample concentration in Tris buffer; data fitted using Chilokotti equation. 

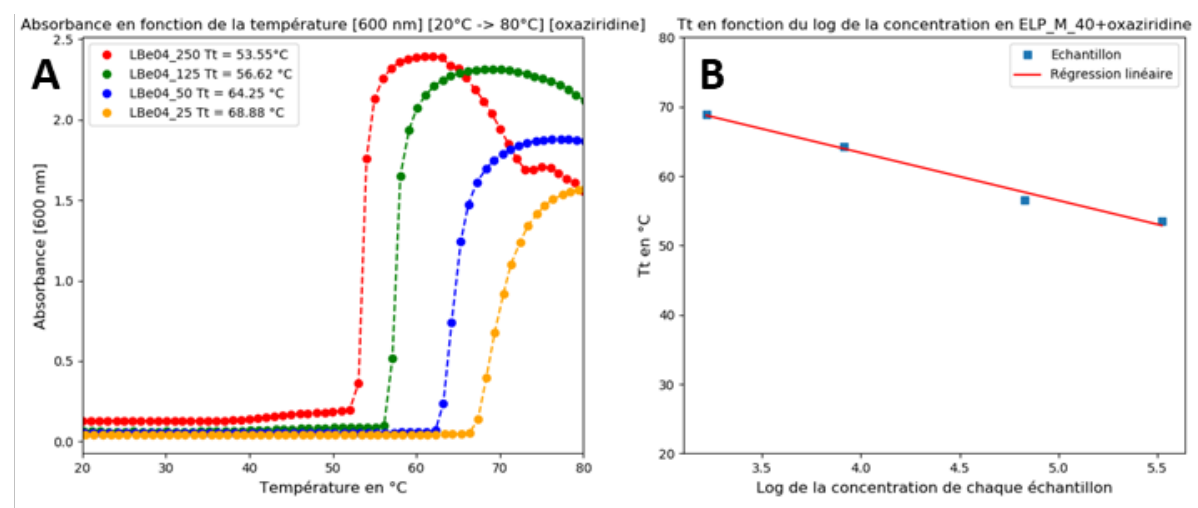

Figure S20. (A) Absorbance of $125 \mu \mathrm{M}$ solutions of compound $1 \mathrm{C}$ in Tris buffer as function of temperature. (B) Tt values of compound 1C, plotted as functions of sample concentration in Tris buffer; data fitted using Chilokotti equation.
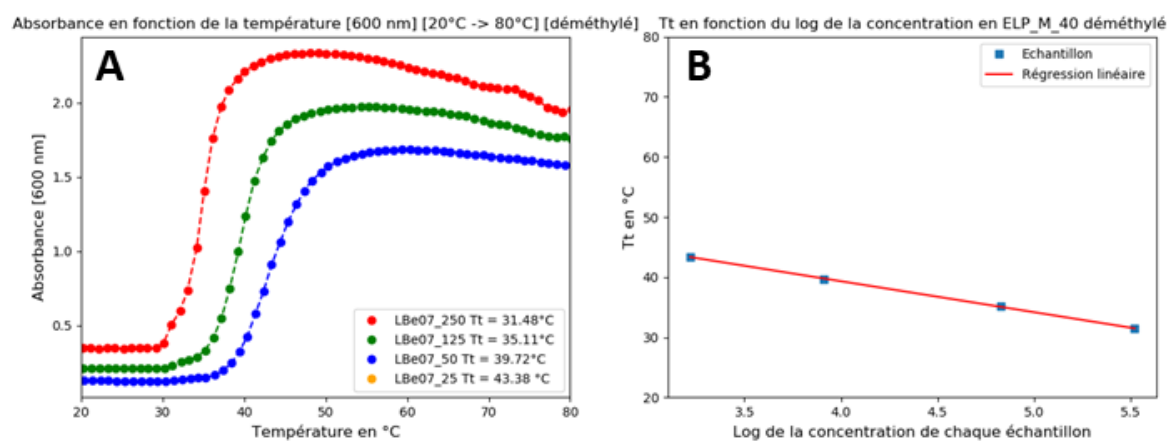

Figure S21. (A) Absorbance of $125 \mu \mathrm{M}$ solutions of compound 1D in Tris buffer as function of temperature. (B) $\mathrm{Tt}$ values of compound $1 \mathrm{D}$, plotted as functions of sample concentration in Tris buffer; data fitted using Chilokotti equation.

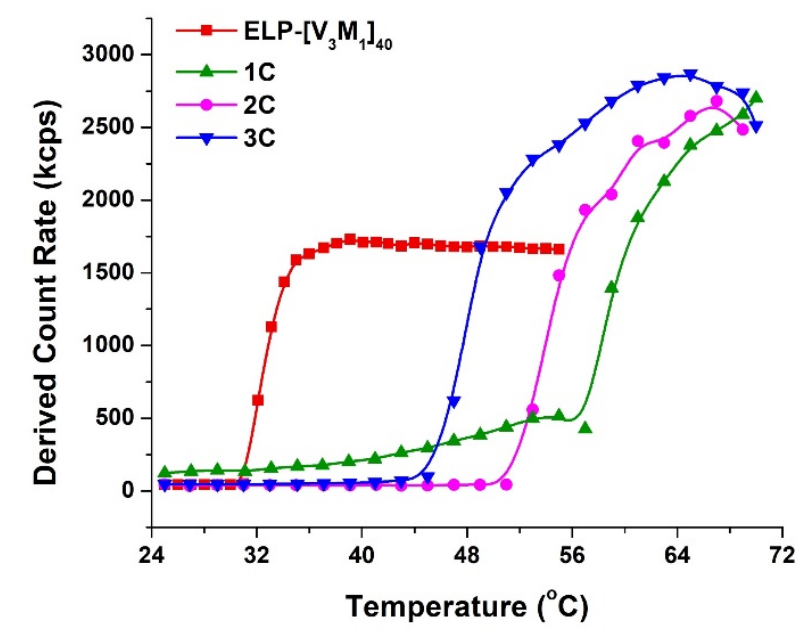

Figure S22. Scattered light intensity of ELP[ $\left[\mathrm{V}_{3} \mathrm{M}_{1}-40\right]$, compound $1 \mathrm{C}, 2 \mathrm{C}$ and $3 \mathrm{C}$ at $125 \mu \mathrm{M}$ in Mili-Q water as function of temperature. 


\begin{tabular}{cccccc}
\hline Concentrations & $\mathrm{ELP}\left[\mathrm{V}_{3} \mathrm{M}_{1}\right]_{40}$ & $1 \mathrm{~A}$ & $1 \mathrm{~B}$ & $1 \mathrm{C}$ & $1 \mathrm{D}$ \\
\hline $25 \mu \mathrm{M}$ & $37^{\circ} \mathrm{C}$ & $>80^{\circ} \mathrm{C}$ & $>70^{\circ} \mathrm{C}$ & $69^{\circ} \mathrm{C}$ & $43^{\circ} \mathrm{C}$ \\
$50 \mu \mathrm{M}$ & $35^{\circ} \mathrm{C}$ & $>80^{\circ} \mathrm{C}$ & $>70^{\circ} \mathrm{C}$ & $64^{\circ} \mathrm{C}$ & $40^{\circ} \mathrm{C}$ \\
$125 \mu \mathrm{M}$ & $33^{\circ} \mathrm{C}$ & $>80^{\circ} \mathrm{C}$ & $>70^{\circ} \mathrm{C}$ & $57^{\circ} \mathrm{C}$ & $35^{\circ}$ \\
$250 \mu \mathrm{M}$ & $30^{\circ} \mathrm{C}$ & $>80^{\circ} \mathrm{C}$ & $>70^{\circ} \mathrm{C}$ & $54^{\circ} \mathrm{C}$ & $31^{\circ} \mathrm{C}$ \\
\hline
\end{tabular}

Table S1. Table summarizing the onset temperature of aggregation $(\mathrm{Tt})$ of the derivatives at $125 \mu \mathrm{M}$ in Tris buffer.
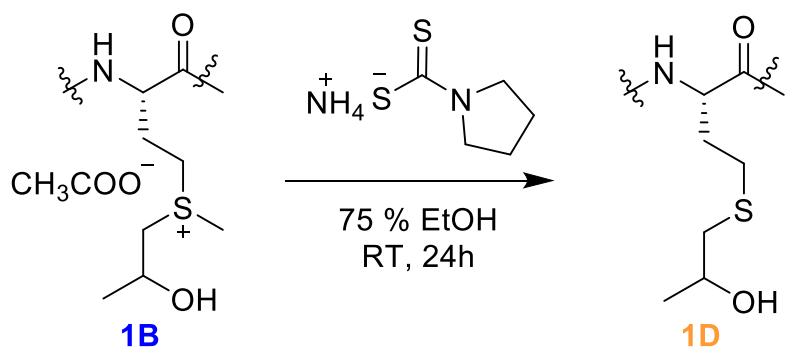

Scheme S1. Demethylation reaction conditions of compound 1B to obtain compound 1D.

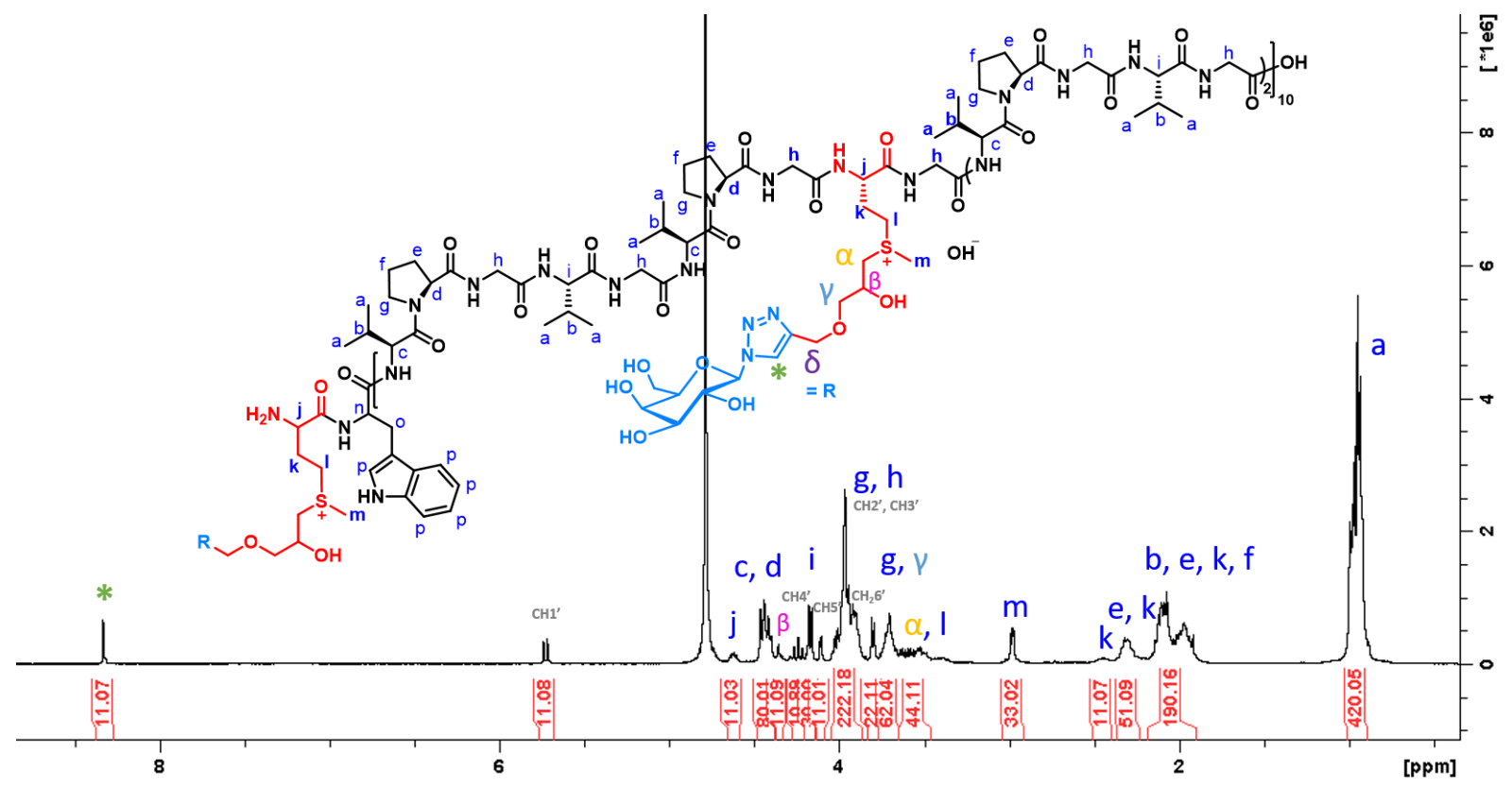

Figure S23. ${ }^{1} \mathrm{H}$ NMR spectrum of compound $4 \mathrm{~B}$ in $\mathrm{D}_{2} \mathrm{O}$ 


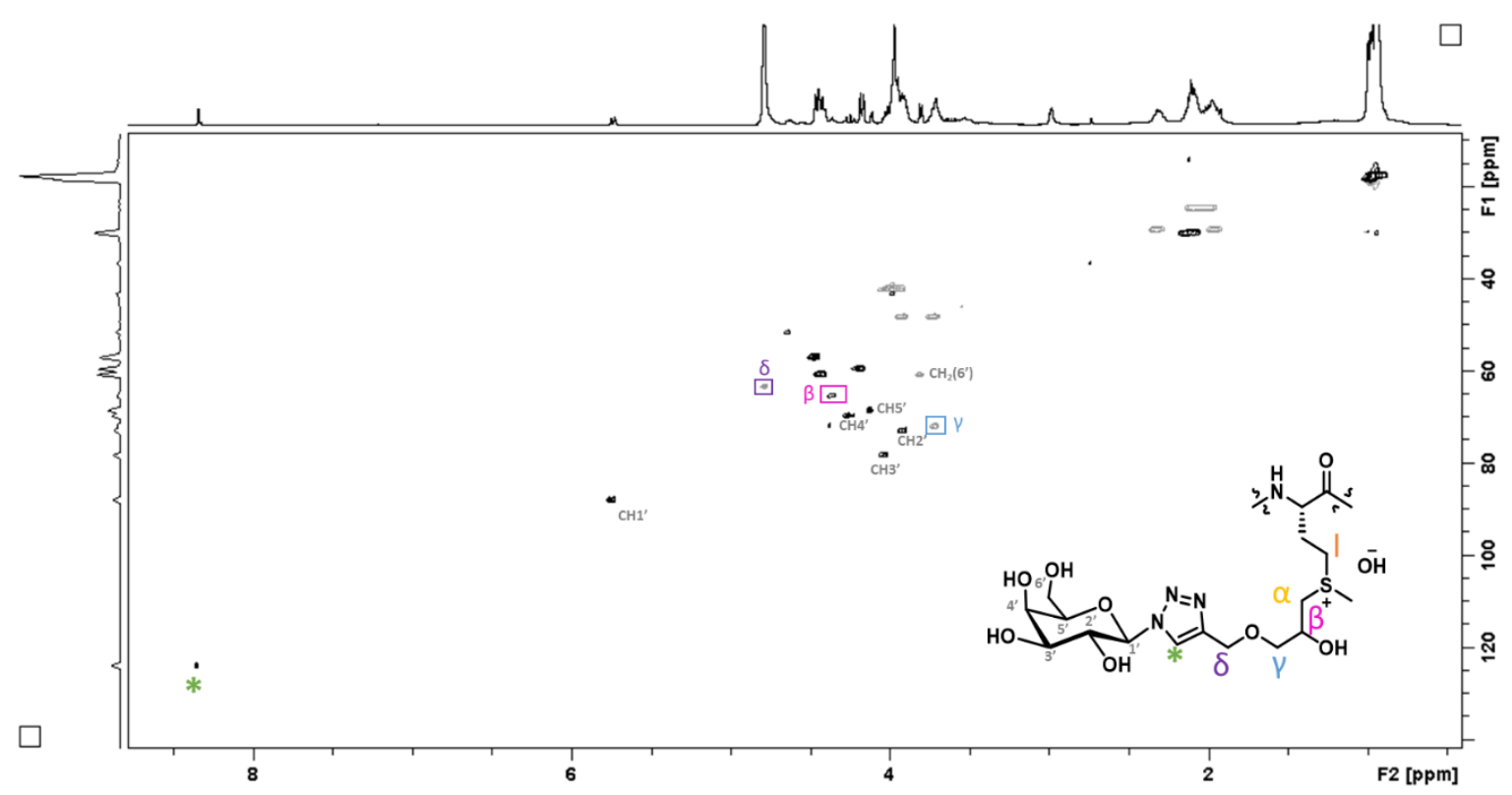

Figure S24. 2D NMR spectrum of compound $4 \mathrm{~B}$ in $\mathrm{D}_{2} \mathrm{O}$, HSQC

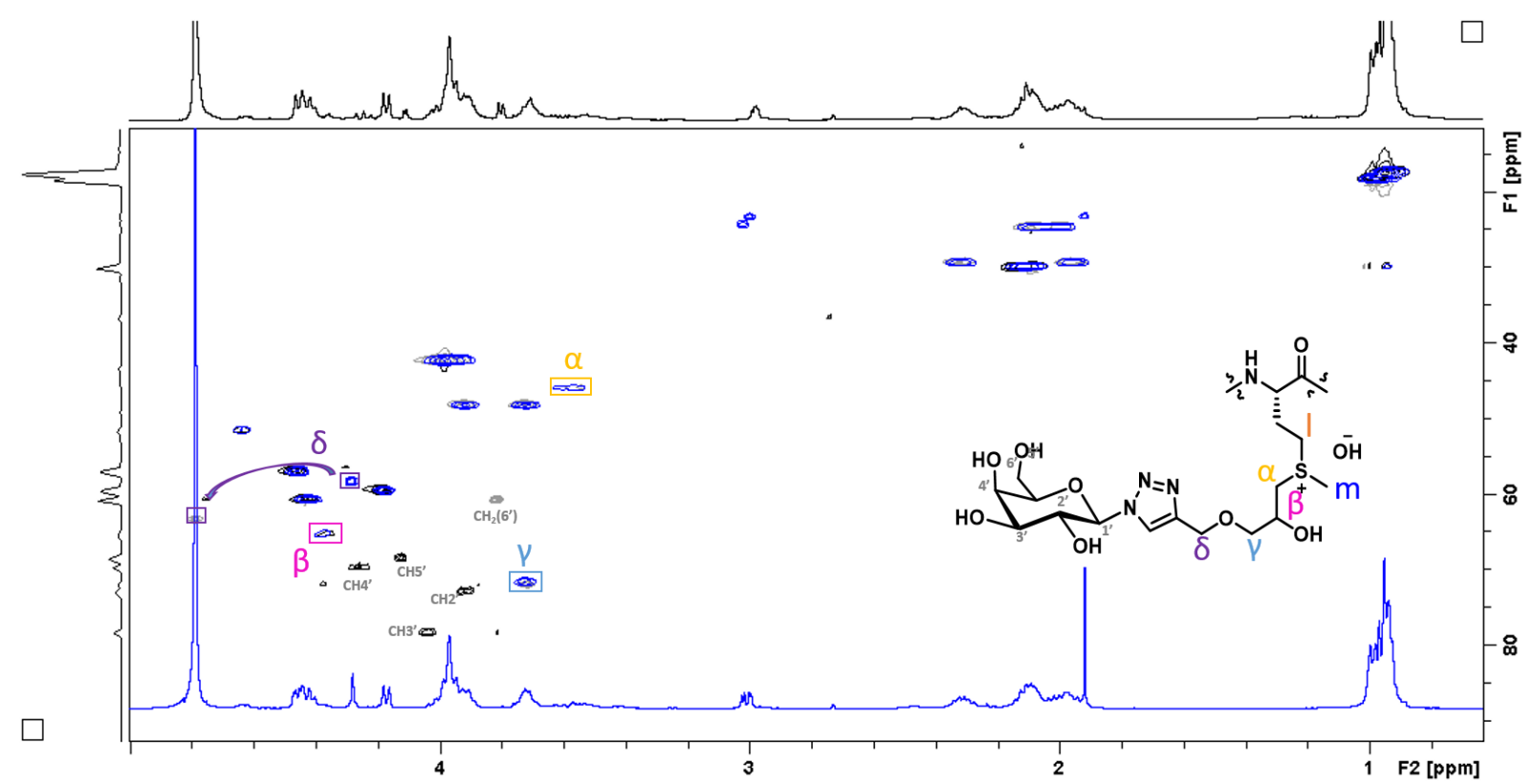

Figure S25. 2D NMR spectrum of compound 4B (in black) and compound 2B (in blue) in $\mathrm{D}_{2} \mathrm{O}, \mathrm{HSQC}$ 


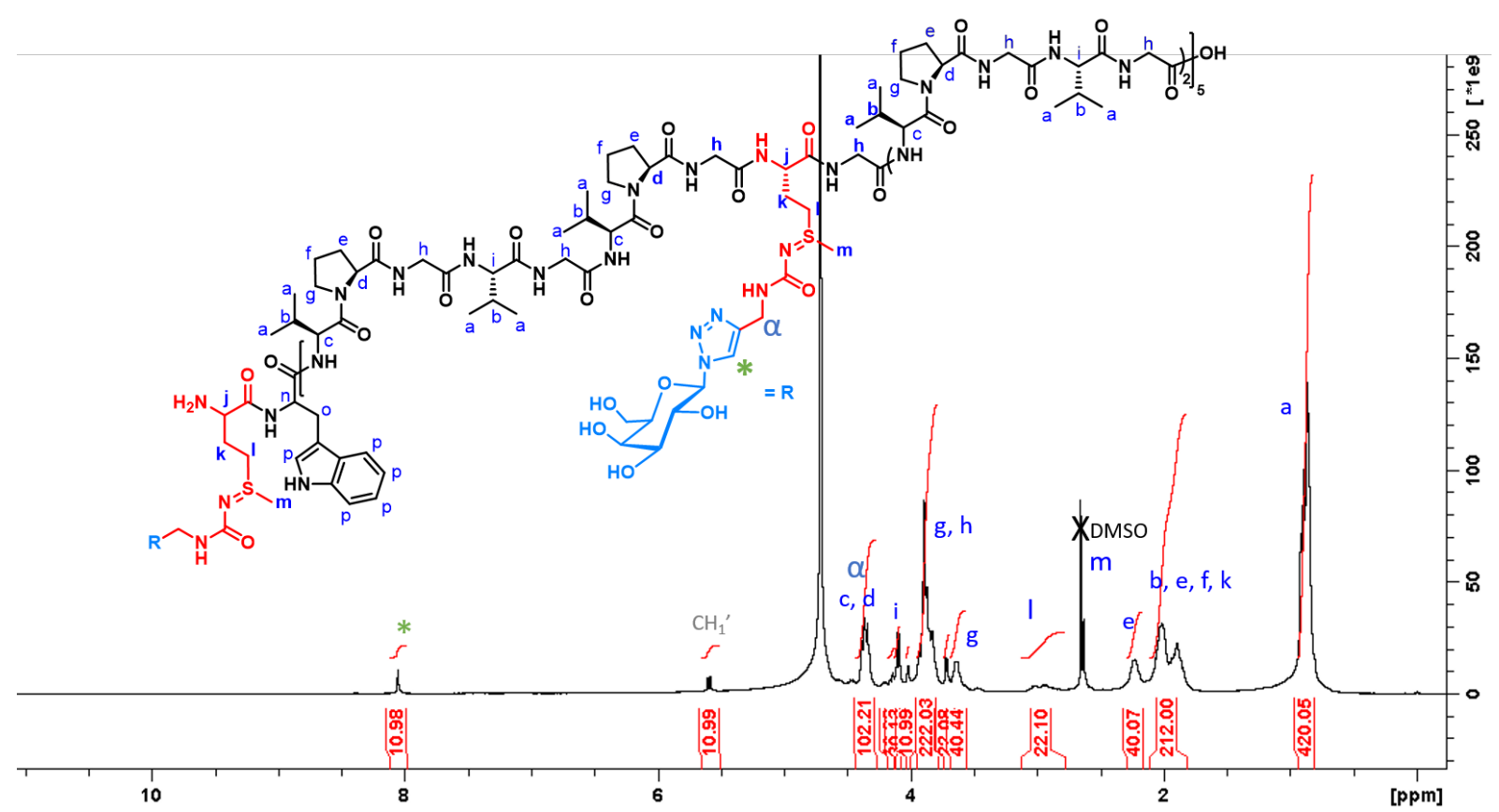

Figure S26. ${ }^{1} \mathrm{H}$ NMR spectrum of compound $4 \mathrm{C}$ in $\mathrm{D}_{2} \mathrm{O}$

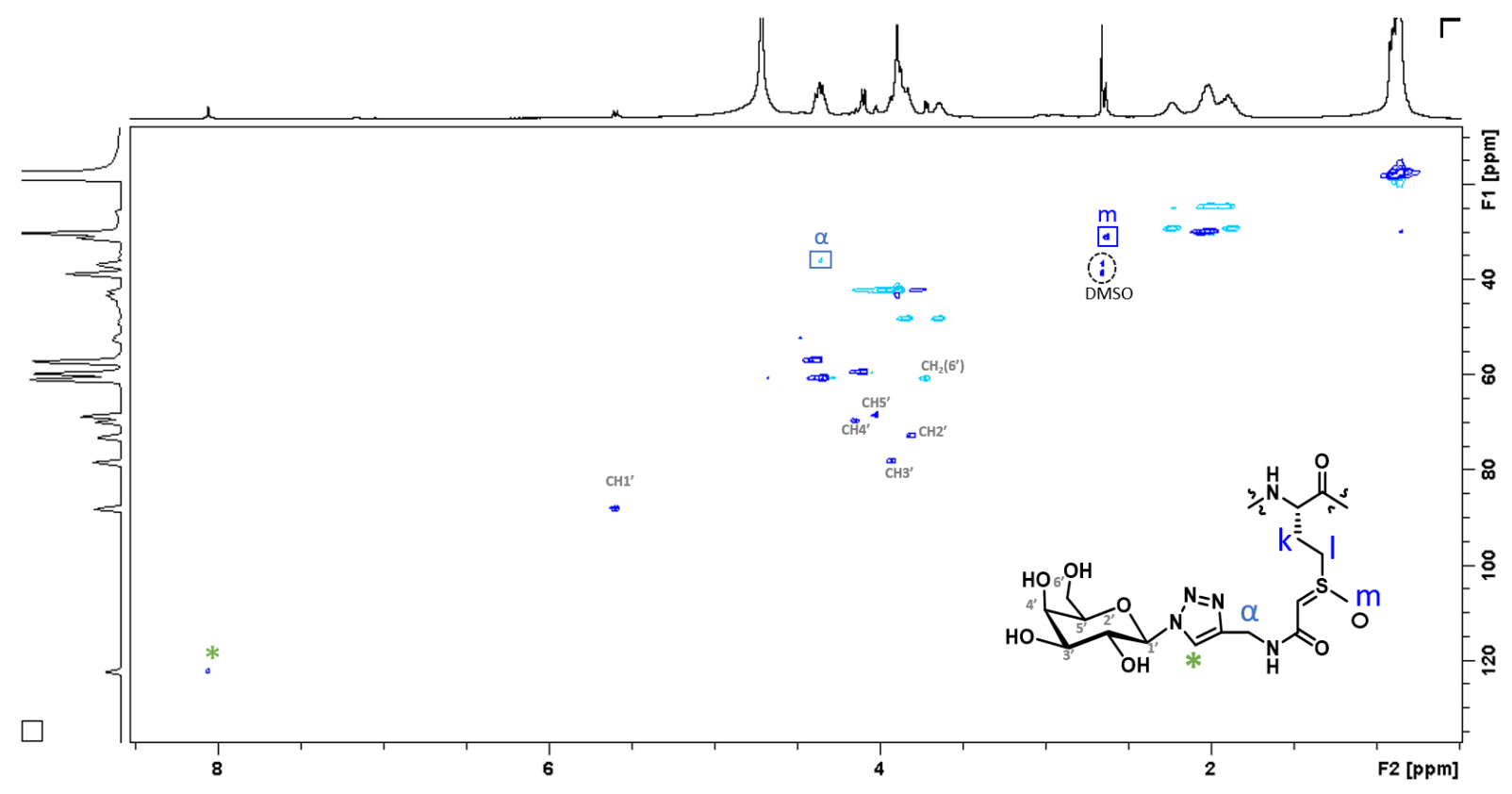

Figure S27. 2D NMR spectrum of compound $4 \mathrm{C}$ in $\mathrm{D}_{2} \mathrm{O}$ 


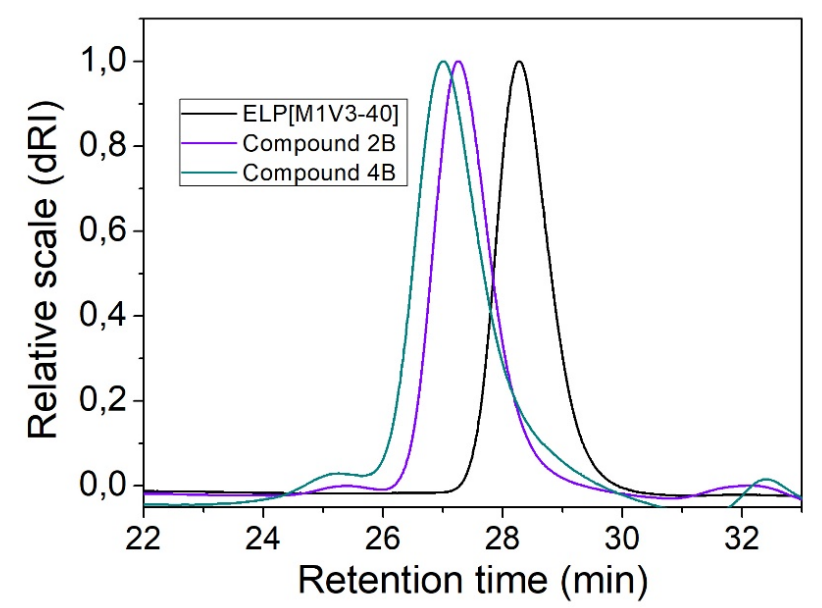

Figure S28. Size exclusion chromatography of ELP $\left[M_{1} V_{3}-40\right]$, compounds $2 B$ and $4 B$ in AcOH/Ammonium Acetate/ACN eluent.

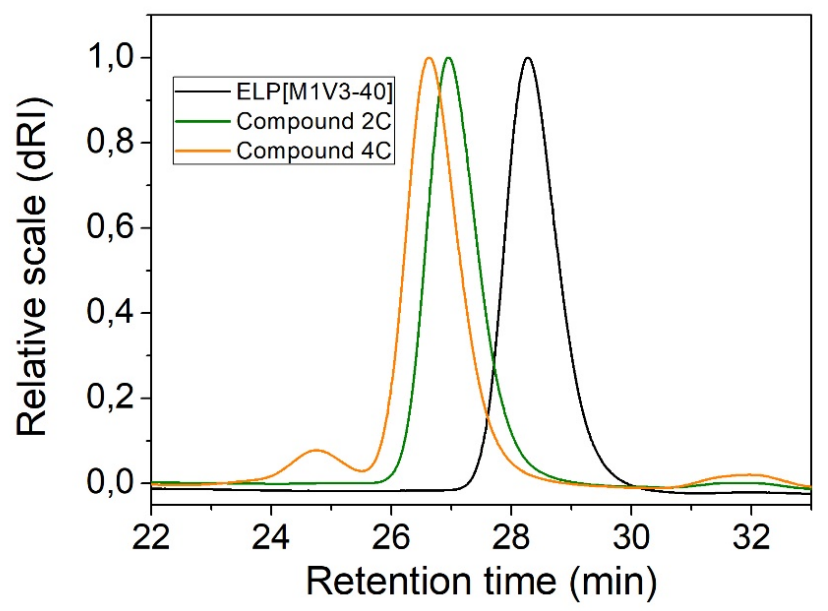

Figure S29. Size exclusion chromatography of ELP $\left[\mathrm{M}_{1} \mathrm{~V}_{3}-40\right]$, compounds $2 \mathrm{C}$ and $4 \mathrm{C}$ in $\mathrm{AcOH} / \mathrm{Ammonium}$ Acetate/ACN eluent.

\section{Reference}

(1) Lin, S.; Yang, X.; Jia, S.; Weeks, A. M.; Hornsby, M.; Lee, P. S.; Nichiporuk, R. V.; Iavarone, A. T.; Wells, J. A.; Toste, F. D.; Chang C. J. Redox-Based Reagents for Chemoselective Methionine Bioconjugation. Science 2017, 355 (6325), 597-602. https://doi.org/10.1126/science.aal3316. 